\title{
A $\beta$ Immunotherapy Protects Morphology and Survival of Adult-Born Neurons in Doubly Transgenic APP/PS1 Mice
}

\author{
Barbara Biscaro, ${ }^{1}$ Olle Lindvall, ${ }^{2,4}$ Christoph Hock, ${ }^{1}$ Christine T. Ekdahl, ${ }^{2,3,4}$ and Roger M. Nitsch ${ }^{1}$ \\ ${ }^{1}$ Division of Psychiatry Research, University of Zurich, 8008 Zurich, Switzerland, ${ }^{2}$ Laboratory of Neurogenesis and Cell Therapy, Section of Restorative \\ Neurology, Wallenberg Neuroscience Center, University Hospital, SE-221 84 Lund, Sweden, ${ }^{3}$ Division of Clinical Neurophysiology, University Hospital, \\ SE-221 85 Lund, Sweden, and ${ }^{4}$ Lund Strategic Research Center for Stem Cell Biology and Cell Therapy, SE-221 84 Lund, Sweden
}

The hippocampus is heavily affected by progressive neurodegeneration and $\beta$-amyloid pathology in Alzheimer's disease (AD). The hippocampus is also one of the few brain regions that generate new neurons throughout adulthood. Because hippocampal neurogenesis is regulated by both endogenous and environmental factors, we determined whether it benefits from therapeutic reduction of $\beta$-amyloid peptide $(\mathrm{A} \beta)$-related toxicity induced by passive $\mathrm{A} \beta$ immunotherapy. $\mathrm{A} \beta$ immunotherapy of 8 -9-month-old mice expressing familial $\mathrm{AD}$-causing mutations in the amyloid precursor protein and presenilin-1 genes with an antibody against $\mathrm{A} \beta$ decreased compact $\beta$-amyloid plaque burden and promoted survival of newly born neurons in the hippocampal dentate gyrus. As these neurons matured, they exhibited longer dendrites with more complex arborization compared with newly born neurons in control-treated transgenic littermates. The newly born neurons showed signs of functional integration indicated by expression of the immediate-early gene Zif268 in response to exposure to a novel object. $A \beta$ immunotherapy was associated with higher numbers of synaptophysin-positive synaptic boutons. Labeling dividing progenitor cells with a retroviral vector encoding green fluorescent protein (GFP) showed that A $\beta$ immunotherapy restored the impaired dendritic branching, as well as the density of dendritic spines in new mature neurons. The presence of cellular prion protein $\left(\mathrm{PrP}^{c}\right)$ on the dendrites of the $\mathrm{GFP}^{+}$newly born neurons is compatible with a putative role of $\operatorname{PrP}^{c}$ in mediating $\mathrm{A} \beta$-related toxicity in these cells. In addition, passive $\mathrm{A} \beta$ immunotherapy was accompanied by increased angiogenesis. Our data establish that passive $\mathrm{A} \beta$ immunotherapy can restore the morphological maturation of the newly formed neurons in the adult hippocampus and promote angiogenesis. These findings provide evidence for a role of $A \beta$ immunotherapy in stimulating neurogenesis and angiogenesis in transgenic mouse models of $\mathrm{AD}$, and they suggest the possibility that $\mathrm{A} \beta$ immunotherapy can recover neuronal and vascular functions in brains with $\beta$-amyloidosis.

\section{Introduction}

The pathology of Alzheimer's disease (AD) is characterized by the accumulation of $\beta$-amyloid peptides $(A \beta)$, neurofibrillary tangles, reactive astrocytes, and activated microglia, leading to cognitive decline and dementia (Haass and Selkoe, 2007; Marcello et al., 2008). Mouse models expressing familial AD-causing mutations reproduce some of these signs, allowing for the exploration of treatments designed to reduce the pathology (Holcomb et al., 1998; Oddo et al., 2003; Kobayashi and Chen, 2005). A $\beta$ immunotherapy can reduce brain $\beta$-amyloid and restore cognition in such transgenic mouse models (Schenk et al., 1999; Bard et al.,

Received May 1, 2009; revised June 10, 2009; accepted July 2, 2009.

This work was supported by the Swiss National Center for Competence in Research on "Neural Plasticity and Repair," by the Swiss National Foundation Grant 3200B-112626/1, and by the Swedish Research Council. We thank Drs. Arnaud Galichet, Riley Crane, Uwe Konietzko and Sebastian Jessberger for helpful discussions. We thank Dr. Karen Duff for providing transgenic PS1 mice and Dr. Carlos Lois and Dr. Wolfgang Kelsch for providing GFPexpressing retrovirus.

A patent application, including data in this manuscript, was filed by the University of Zurich and licensed to Biogenldec, Inc. Four authors (B.B., O.L., C.T.E., R.M.N.) are listed as inventors on the patent application. R.M.N. and C.H. are cofounders, shareholders, and board members of Neurimmune Therapeutics AG.

Correspondence should be addressed to Roger M. Nitsch, Division of Psychiatry Research, University of Zürich, August-Forel Strasse 1, 8008 Zürich, Switzerland. E-mail: nitsch@bli.uzh.ch.

DOI:10.1523/JNEUROSCI.2055-09.2009

Copyright $\odot 2009$ Society for Neuroscience 0270-6474/09/2914108-12\$15.00/0
2000; Morgan et al., 2000; DeMattos et al., 2001). In patients with $\mathrm{AD}, \mathrm{A} \beta$ vaccination cleared brain $\mathrm{A} \beta$ and slowed cognitive decline in a subcohort of patients (Hock et al., 2003; Nicoll et al., 2003). Although both $\mathrm{A} \beta$ clearance and stabilized cognition correlated with titers of anti-A $\beta$ antibodies, the initial clinical trial was prematurely interrupted because of side effects, and it is currently unclear whether reducing brain $A \beta$ is sufficient to halt disease progression and whether therapeutic $\mathrm{A} \beta$ clearance should start before the onset of neurodegeneration (Hock et al., 2003; Holmes et al., 2008). Adult neurogenesis continues throughout life in two restricted brain regions (Altman and Das, 1965; Eriksson et al., 1998). In the dentate gyrus, new granule cells contribute to the maintenance of hippocampal functions, including mood regulation, learning, and memory (Shors, 2008; Zhao et al., 2008). Enriched environment, exercise, pharmacological compounds, as well as stroke, epilepsy, and neurodegeneration, affect adult neurogenesis and enhanced neurogenesis may restore functions in neurodegenerative diseases including $\mathrm{AD}$ (Bengzon et al., 1997; Kempermann et al., 1997; Parent et al., 1997; van Praag et al., 1999; Arvidsson et al., 2002; Curtis et al., 2003; Santarelli et al., 2003; Lie et al., 2004; Kuhn et al., 2007; Abdipranoto et al., 2008). Initial signs for increased neurogenesis in postmortem brains obtained from patients with $\mathrm{AD}$ were not confirmed by subsequent studies suggesting impaired maturation of new neurons 
(Jin et al., 2004; Li et al., 2008). Because aggregated oligomeric forms of $A \beta$ are neurotoxic in vivo (Lesne et al., 2006; Shankar et al., 2008), we explored whether reducing brain $\mathrm{A} \beta$ by $\mathrm{A} \beta$ immunotherapy has a protective role in adult neurogenesis in doubly transgenic amyloid precursor protein/presenilin-1 (APP/PS1) mice. In a prior experiment, active vaccination increased neurogenesis in young transgenic mice (Becker et al., 2007). It is unknown, however, whether passive $A \beta$ immunotherapy can rescue adult neurogenesis in aged transgenic mice with $\beta$-amyloidrelated impairments of neurogenesis. We addressed this question by treating $8-9$-month-old APP/PS1 mice characterized by preexisting $\beta$-amyloid pathology with weekly injections of an antibody against $\mathrm{A} \beta$ over a 3.5 month period. We found that $\mathrm{A} \beta$ immunotherapy increased numbers of new neurons, these showed morphological signs of synaptic activity, improved dendritic branching, and restored numbers of dendritic long-thin, stubby, and mushroom spines. Moreover, $\mathrm{A} \beta$ immunotherapy increased angiogenesis in the dentate gyrus.

\section{Materials and Methods}

Animals and treatments. Heterozygous doubly transgenic mice expressing both human mutant APP (Tg 2576; Hsiao et al., 1996) and human mutant PS1 (mutation: M146L) were generated by crossing heterozygous $\mathrm{Tg} 2576$ mice on a hybrid C57BL6/J $\times \mathrm{FVB} / \mathrm{N} \times \mathrm{SJL} / \mathrm{J}$ background, with no obvious signs of embryonic lethality, with PS1-transgenic mice on a hybrid Swiss Webster $\times$ B6D2 background. The APP/PS1transgenic mice were compared with age-matched littermates or nontransgenic (non-tg) mice with the same hybrid background. Genotypes were determined by PCR. Both males and females were housed in standard cages with females in groups of two to four and males single-caged under $12 \mathrm{~h}$ light/dark conditions with ad libitum access to water and food. The $\alpha-\mathrm{A} \beta$ antibody used throughout these experiments is a chimeric monoclonal antibody consisting of human variable domains and mouse IgG2a constant regions. It selectively recognizes with high-affinity (low nM range) aggregated forms of $\mathrm{A} \beta 1-40$ and $\mathrm{A} \beta 1-42$, as well as $\beta$-amyloid plaques on tissue sections obtained from human or transgenic mouse brains. The antibody is specific for aggregated $\mathrm{A} \beta$ and does not cross-react with the unprocessed full-length APP.

In a first experiment, at 8 months of age, 14 APP/PS1 mice were either treated with $\alpha-\mathrm{A} \beta$ ( $n=7$, six males and one female) or an irrelevant control antibody with the same isotype (IgG2) raised against bovine herpes virus (clone 2H6-C2; European Collection of cell cultures, Ecacc) (ct ab) ( $n=5 ; 4$ males and 1 female). The antibodies were administered once a week at a dose of $5 \mathrm{mg} / \mathrm{kg}$ i.p. for 3.5 months before perfusion. In a second experiment, 15 mice were injected with green fluorescent protein (GFP)-expressing retrovirus into the dentate gyrus at 3 months of age, 1 month after the beginning of either passive $A \beta$ immunization or vehicle treatment; $n=5$ ( 2 males and 3 females) APP/PS1 mice with $\alpha$-A $\beta$ treatment ( $5 \mathrm{mg} / \mathrm{kg}$ i.p.) and $n=5$ ( 2 males and 3 females) APP/ PS1 and $n=5$ ( 2 males and 3 females) non-tg mice with vehicle treatment (PBS, $100 \mu \mathrm{l} / 10 \mathrm{~g}$ body weight, i.p.) for 2 months before perfusion, starting at 2 months of age. In general, after a 5 min transport from the animal facility within the same building, mice were placed in their home cages under a hood for 30 min before anesthesia and transcardial perfusion. This procedure caused no increases in expression of the immediate early gene Zif268 in the brains. To experimentally stimulate immediate early gene expression, mice were exposed for $10 \mathrm{~min}$ to a novel object by placing a quarter of an apple wrapped in tin foil into their home cages. All mice intensively explored the novel object. The novel object exposure was followed by a $10 \mathrm{~min}$ interval until anesthesia was initiated and followed by an additional 15 min interval until brains were perfused. This experimental setup resulted in the consistent appearance of Zif268 protein in discrete foci in cells throughout the brain cortex and hippocampus, including the nuclei of bromodeoxyuridine-positive $\left(\mathrm{BrdU}^{+}\right)$ newly born neurons in the SVZ/GCL. The presence of Zif268 protein as early as $35 \mathrm{~min}$ after the onset of novel object exposure is compatible with the known time dependence of immediate early gene expression in brain following stimulation (Richardson et al., 1992; Guzowski et al., 1999; Kubik et al., 2007).

To exclude nonspecific effects of $A \beta$ immunotherapy on neurogenesis, we used non-tg, wild-type mice that do not express human APP or have $\beta$-amyloid pathology. These mice were treated with either vehicle (PBS, $100 \mu \mathrm{l} / 10$ g body weight, i.p.; $n=5 ; 2$ males and 3 females) or $\alpha$-A $\beta$ ( $5 \mathrm{mg} / \mathrm{kg}$ i.p.; $n=4 ; 1$ male and 3 females) for 10 weeks before perfusion, starting at 2 months of age.

In the different experiments, there was a good balance between numbers of male and female mice, and results were, therefore, pooled. Because of low numbers of either male or female animals, a reliable statistical comparison could not be made, but no obvious influence of gender on any parameter of neurogenesis was detected. All experimental procedures followed guidelines set by the Swiss veterinary cantonal office for the use and care of laboratory animals (License $\mathrm{Nr} 48 / 08$ ).

Bromodeoxyuridine labeling. Mice were injected with the thymidine analog BrdU (50 mg/kg i.p.; dissolved in potassium PBS (KPBS)) twice daily for 2 weeks, for labeling of mitotic cells (Dolbeare, 1995), starting 1 month before perfusion. In non-tg mice subjected to either vehicle or $\mathrm{A} \beta$ immunotherapy, $\mathrm{BrdU}$ ( $50 \mathrm{mg} / \mathrm{kg}$ i.p.; twice daily for $3 \mathrm{~d}$ ) was injected 1 month after the beginning of the treatment.

Retrovirus-GFP labeling. An oncoretroviral vector derived from the Moloney sarcoma virus and expressing GFP under control of the Rous sarcoma virus promoter (MolRG) was used. Transfer vector and helper vectors were gifts from Wolfgang Kelsch and Carlos Lois (Massachusetts Institute of Technology, Cambridge, MA). The viral solution was prepared by cotransfection of HEK293FT cells (Invitrogen) using calcium-phosphate precipitation. After $48 \mathrm{~h}$, conditioned media were concentrated by two sequential ultracentrifugations in sucrose gradients. Viral particles were resuspended in sterile PBS, aliquoted, and stored at $-80^{\circ} \mathrm{C}$ until use. Viral concentrations $\left(10^{8-9} \mathrm{cfu} / \mathrm{ml}\right)$ were determined by serial dilutions on HEK293FT cells, and the number of $\mathrm{GFP}^{+}$cells was counted $48 \mathrm{~h}$ after infection using flow cytometry. For labeling of the new neurons, mice were deeply anesthetized with ketamin/xylaxine and given unilateral injections of the retroviral vector ( $1.5 \mu \mathrm{l}$ at $0.2 \mu \mathrm{l} / \mathrm{min}$ ) into the dentate gyrus (coordinates: $2 \mathrm{~mm}$ posterior and $1.5 \mathrm{~mm}$ lateral from bregma and $2.3 \mathrm{~mm}$ ventral from skull).

Immunohistochemistry. Mice were anesthetized with ketamin/xylaxine and transcardially perfused with $50 \mathrm{ml}$ of PBS, followed by $100 \mathrm{ml}$ of ice-cold $4 \%$ paraformaldehyde in $0.1 \mathrm{M} \mathrm{PBS}, \mathrm{pH}$ 7.4. Brains were removed, post-fixed overnight in the same medium, and put in $20 \%$ sucrose in $0.1 \mathrm{~m}$ phosphate buffer for $24 \mathrm{~h}$. Coronal sections (30 or $40 \mu \mathrm{m}$ for the analyses following retrovirus injections) were cut on a sliding microtome and stored in cryoprotective solution. For immunohistochemistry, preincubation with appropriate normal sera was carried out for $1 \mathrm{~h}$ at room temperature. For epitope retrieval of BrdU, phosphohistone $\mathrm{H} 3$ (p-H3) and proliferating cell nuclear antigen (PCNA), freefloating sections were denatured in $1 \mathrm{M} \mathrm{HCl}$ for $30 \mathrm{~min}$ at $+65^{\circ} \mathrm{C}$. Primary antibodies were as follows: rabbit anti-ionized calcium-binding adapter molecule 1 (Iba1) [a marker for microglia/macrophages (Imai et al., 1996); 1:1000; Wako Chemicals]; rat anti-CD11b (a marker for activated microglia; 1:200; BD Pharmingen); mouse anti-human $\beta$-amyloid (6E10) (1:1000; Covance); rat anti-BrdU (1:100; Oxford Biotec); mouse anti-neuronal nuclei marker (NeuN) (1:100; Millipore Bioscience Research Reagents); rabbit anti-S100 $\beta$ (a marker for astrocytes; 1:5000; SWANT); rabbit anti-C terminus of the transcription factor Zif268 [a marker for synaptic activity (Beckmann and Wilce, 1997); 1:250 (Santa Cruz Biotechnology)]; mouse anti-polysialic acid-neural cell adhesion molecule (PSA-NCAM) [a marker for immature neurons (Rougon et al., 1982); 1:2000; AbCys]; mouse anti-synaptophysin (SYN) (a marker for synapses; 1:200; Sigma); rabbit anti-mouse glucose transporter 1 (Glut1), a marker for glucose transporter 1 highly expressed in endothelial cells of barrier tissues such as the blood-brain barrier (1:500; Alpha Diagnostic), goat anti-prion protein [(Hantman and Perl, 2005); 1:400; Millipore Bioscience Research Reagents], and biotinylated-isolectin IB4 (1:200; Invitrogen). Isolectin-IB4 binds to microglia, group B erythrocytes, perivascular cells, and endothelial cells and can be used to stain adult brain vasculature (Ernst and Christie, 2006).

Free-floating sections were incubated overnight at $+4^{\circ} \mathrm{C}$. Secondary antibodies for detection were $\mathrm{Cy} 3$-conjugated donkey-anti-rabbit/rat, 
FITC-conjugated goat anti-mouse/rabbit, Cy5-conjugated donkey anti-mouse, biotinylated anti-goat, Cy5-conjugated streptavidin and for lectin-staining FITC-conjugated streptavidin (all 1:200; Jackson ImmunoResearch Laboratories) with incubation for $2 \mathrm{~h}$ at room temperature in the dark. Rinsing in $0.25 \%$ Triton X-100 was carried out between each incubation. To detect $\beta$-amyloid plaques decorated with the antibody used for passive immunotherapy, sections were incubated with Cy3-conjugated donkey-anti-mouse (1:200; Jackson ImmunoResearch Laboratories). For single-staining with rabbit anti $\mathrm{p}-\mathrm{H} 3$, specifically expressed only from late $G_{2}$ interphase until anaphase, thus providing the actual number of dividing cells (Hendzel et al., 1997) (1: 400; Upstate Biotechnology) or with mouse anti-PCNA [expressed in early $\mathrm{G}_{1}$ and $\mathrm{S}$ phases (Bravo and Macdonald-Bravo, 1987); 1:200; Santa Cruz Biotechnology], avidin-biotin peroxidase complex (Elite ABC kit; Vector Laboratories), 3,3'-diaminobenzidine and hydrogen peroxide were used. Chromogenic visualization included pretreatment with blocking of endogenous peroxidase activity with $3 \% \mathrm{H}_{2} \mathrm{O}_{2}$ and $10 \%$ methanol. Sections were mounted on chrom-gelatin-coated microscope slides (Super-frost-plus; Menzel) and coverslipped with aqueous anti-fading mounting medium (PVA-DABCO). Thioflavin-S (ThioS) staining for fibrillar $\mathrm{A} \beta$ was done as described previously (Schmidt et al., 1995). In short, floating sections from APP/PS1 mice were washed in KPBS and mounted on chrom-gelatin-coated glass slides before being processed. After treatment for $10 \mathrm{~min}$ with $0.25 \%$ potassium permanganate, sections were washed in KPBS and incubated in $1 \%$ potassium metabisulfite and $1 \%$ oxalic acid until they appeared white. Sections were then floated $3 \mathrm{~s}$ in $0.25 \%$ acetic acid, washed in water and stained for 5 min with a solution of $0.015 \%$ Thio-S in $50 \%$ ethanol. Finally, sections were washed in $50 \%$ ethanol and in water, then dried, and coverslipped with PVADABCO. For Prussian blue staining for hemosiderin, whose presence is an indication of a past microhemorrhage event, sections were mounted on coated slides and then stained with equal solutions of $20 \% \mathrm{HCl}$ and $10 \%$ potassium ferrocyanide $\left[\mathrm{K}_{4} \mathrm{Fe}(\mathrm{CN})_{6}{ }^{*} 3 \mathrm{H}_{2} \mathrm{O}\right]$ in water for $30 \mathrm{~min}$ at $37^{\circ} \mathrm{C}$. All chemicals were from Sigma. Control stainings included omission of the primary antibody and/or use of different tissues known to be positive for the specific antibody (e.g., tonsils for $\mathrm{p}-\mathrm{H} 3$ and hippocampus from young mice exposed to novel enviroment for Zif268).

Stereology and microscopic analyses. All measurements were performed by an observer blind to animal identifications. Immunohistochemical stainings were examined with an Inverted Leica DM IRE2 fluorescence and light microscope. Numbers of immunoreactive cells were counted bilaterally in the granule cell layer (GCL), and within one cell diameter below this region in the subgranular zone (SGZ), throughout the entire dentate gyrus. Stereological estimations of the total number of $\mathrm{BrdU}^{+}$ and PSA-NCAM ${ }^{+}$in the SGZ/GCL, as well as numbers of Glut ${ }^{+}$and IsolectinB4 ${ }^{+}$blood vessels in the dentate gyrus, were performed using the optical fractionator method (Gundersen and Jensen, 1987; West et al., 1991). Six to eight coronal sections were analyzed per animal using the Leica DM4000B microscope with a $100 \times$ oil objective, Olympus DP71 color digital camera, and newCAST software (Visiopharm). For systematic sampling, the frame area was set to $3590 \mu \mathrm{m}^{2}$ with a sampling interval of $226 \mu \mathrm{m}$ at the $\mathrm{x}$ and $\mathrm{y}$ level, and the optical dissector constituting a $15-\mu \mathrm{m}$-thick fraction of the total section thickness (measuring $22-25 \mu \mathrm{m}$ after processing). Neither the area for counting nor the thick-
Table 1. Morphological phenotypes of Iba1 plus microglia and area fraction for CD11b plus activated microglia in APP/PS1 doubly transgenic mice subjected to $A \beta$ immunotherapy

\begin{tabular}{|c|c|c|c|}
\hline Region & Microglia type/Area fraction & Control antibody & $\mathrm{A} \beta$ Immunotherapy \\
\hline \multirow[t]{4}{*}{ SGZ/GCL } & $\%$ ramified lba $1^{+}$ & $36.4 \pm 22.5$ & $24.4 \pm 4.9$ \\
\hline & $\%$ intermediate lba ${ }^{+}$ & $49.3 \pm 3.3$ & $57 \pm 4.8$ \\
\hline & $\%$ amoeboid lba ${ }^{+}$ & $13 \pm 2.9$ & $15.5 \pm 2.7$ \\
\hline & $\%$ round lba ${ }^{+}$ & $1.3 \pm 0.5$ & $3.2 \pm 1.4$ \\
\hline \multirow[t]{4}{*}{ Hilus } & $\%$ ramified lba ${ }^{+}$ & $20.5 \pm 2.9$ & $12.4 \pm 3.0$ \\
\hline & $\%$ intermediate lba ${ }^{+}$ & $57.7 \pm 7.2$ & $59.8 \pm 3.4$ \\
\hline & $\%$ amoeboid lba $1^{+}$ & $13.7 \pm 4.2$ & $21.5 \pm 4.7$ \\
\hline & $\%$ round $\mathrm{lba}^{+}$ & $3.3 \pm 1.1$ & $6.3 \pm 1.1$ \\
\hline \multirow[t]{4}{*}{ Septum } & $\%$ ramified Iba ${ }^{+}$ & $18.3 \pm 3.3$ & $17.7 \pm 3.4$ \\
\hline & $\%$ intermediate $\mathrm{lba}{ }^{+}$ & $57.7 \pm 7.2$ & $49.8 \pm 3.7$ \\
\hline & $\%$ amoeboid lba ${ }^{+}$ & $15.4 \pm 5.3$ & $21.4 \pm 2.9$ \\
\hline & $\%$ round lba ${ }^{+}$ & $8.6 \pm 3.2$ & $11.1 \pm 2.7$ \\
\hline Hippocampus & $\%$ area $\mathrm{CD}_{11 \mathrm{~b}}{ }^{+}$ & $0.50 \pm 0.10$ & $0.65 \pm 0.11$ \\
\hline Septum & $\%$ area $\mathrm{CD} 11 \mathrm{~b}^{+}$ & $0.84 \pm 0.20$ & $0.98 \pm 0.31$ \\
\hline
\end{tabular}

Morphological subtypes of Iba1 plus microglia: ramified and intermediate represent quiescent and amoeboid and round represent activated microglia. No significant differences were observed between groups. Values are means \pm SEM; $n=5$ (control antibody) and $n=7$ (A $\beta$ immunotherapy).

ness of the analyzed sections differed between groups, which allowed for comparisons of cell counts. The SGZ/GCL and dentate hilus volumes were measured using the same stereological equipment in the same sections. The intersections of $\mathrm{NeuN}$-stained dentate gyri with a digitally over 

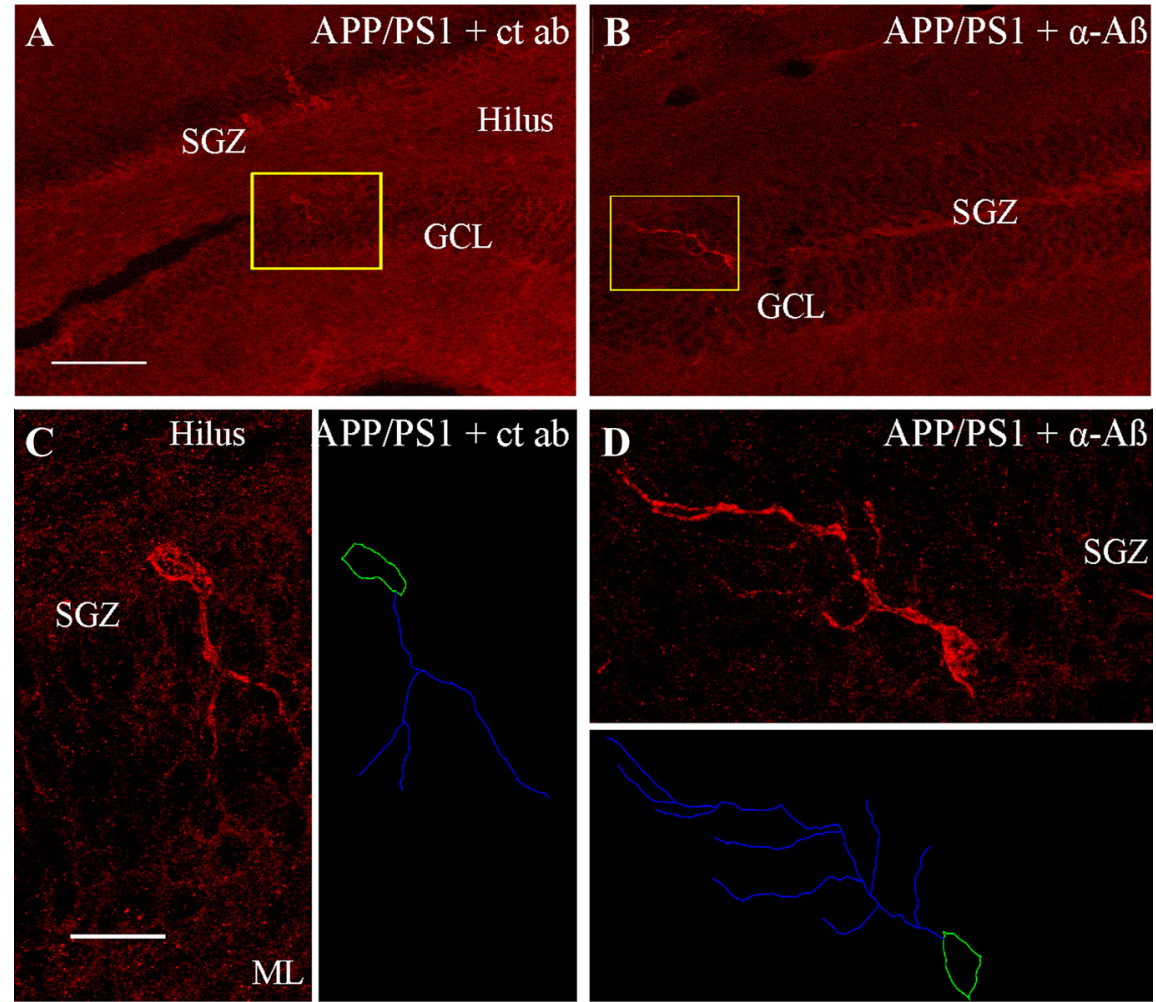

Figure 2. $\quad A \beta$ immunotherapy increased neurogenesis and dendritic arborization of newly born neurons in 11-12-month-old APP/PS1 mice. $A \beta$ immunotherapy significantly increased numbers of mature $B r d U^{+} / \mathrm{NeuN}^{+}$; this increase was accompanied by a trend for higher numbers of immature PSA-NCAM + neurons (APP/PS1 +ct ab: $306 \pm 31$ vs APP/PS1 $+\alpha-A \beta: 452 \pm 42$ $\mathrm{BrdU}^{+} / \mathrm{NeuN}^{+}$cells; $p<0.05 ;$ and APP/PS1 + ct ab: $219 \pm 79$ vs APP/PS1 $+\alpha-A \beta: 842 \pm 275$ PSA-NCAM $^{+}$cells; $\left.p=0.06\right)$ $\boldsymbol{A}, \boldsymbol{B}$, Representative low-magnification images of PSA-NCAM ${ }^{+}$neurons in the dentate gyrus of control-treated $(\boldsymbol{A})$ and $A \beta$ immunotherapy-treated $(\boldsymbol{B})$ mice. $A \beta$ immunotherapy significantly increased the number of dendrites of PSA-NCAM ${ }^{+}$neurons in APP/PS1 mice and the length of dendrites of PSA-NCAM ${ }^{+}$neurons in APP/PS1 mice (number of dendrites per cell: APP/PS1 $+C$ $\mathrm{ab}: 2.45 \pm 0.3$ vs APP/PS1 $+\alpha-A \beta: 4 \pm 0.4 ; p<0.01$; and length of dendrites: APP/PS1 + ct ab: $54.4 \pm 7$ vs APP/PS1 $+\alpha-A \beta$ $85.5 \pm 10 \mu \mathrm{m} ; p<0.01) .(\mathbf{D}, \mathbf{D}$, High-magnification confocal details, including corresponding computer renderings resulting from quantitative NeuronJ analyses of the cells shown in the yellow squares in $\boldsymbol{A}$ and $\boldsymbol{B}$, respectively, taken from comparable regions within the dentate gyrus. Scale bars: $A, 60 \mu \mathrm{m} ; C, 20 \mu \mathrm{m} . N=40$ cells were analyzed per group. Unpaired $t$ test.

imposed counting grid were counted in 8-10 coronal sections with a $40 \times$ objective. A maximum of 150-200 intersecting points (area per point: 0.078 $\mathrm{mm}^{2}$ ) were counted per animal, and the volume was estimated applying Cavalieri's principle (Gundersen et al., 1988). Because of their small numbers, all p-H3 ${ }^{+}$, BrdU $^{+}$, and PSA-NCAM ${ }^{+}$cells in the SGZ/GCL were counted in each section. Colocalization of up to 50 double- or triple-stained BrdU ${ }^{+}$cells with NeuN/S100 $\beta / Z$ if268 was validated using a confocal scanning microscope (Leica TCS/SP2; Leica) with Argon laser 488, HeNE laser, 568 and 633 excitation filters. Numbers of blood vessels bilaterally in the entire dentate gyrus of antibody-treated APP/PS1 mice were estimated as described elsewhere (Lee et al., 2005) using the same stereological settings as described above. Briefly, the total number of branching points (defined as the point in which a single capillary branches into two, forming a Y) was counted using the optical dissector. If these points are set as the counting targets, twice this number is equal to the number of capillary segments. Since thick vertical uniform random sections were used, the length of blood vessels was estimated via counting the intersections between capillaries and "virtual" isotropic planes projected through the section by computer-assisted stereology (Larsen et al., 1998). SYN-positive presynatic terminals were counted bilaterally in the molecular layer (ML) of three hippocampal sections using a Leica DM4000B microscope with a $100 \times$ oil objective, Olympus DP71 color digital camera, and newCAST software (Visiopharm) with frame area set to $250 \mu \mathrm{m}^{2}$, with $200 \mu \mathrm{m}$ sampling intervals at the $\mathrm{x}$ and $\mathrm{y}$ levels, and with the optical dissector constituting 2.5 - $\mu \mathrm{m}$-thick fractions of the total section thickness.

The morphology of Iba1 ${ }^{+}$microglia in the dentate gyrus and septum was characterized as ramified, intermediate, amoeboid or round profile, as described elsewhere (Thored et al., 2009), and the percentage of the respective phenotype was calculated over the total number of Ibal ${ }^{+}$ cells considered ( $\sim 90$ cells).

Morphological analysis of new immature neurons. To determine dendrite length and branching, PSA-NCAM ${ }^{+}$cells $(n=40$ from each group) were analyzed using a Leica DM4000 microscope with a $63 \times$ water objective and a digital zoom of 2 . On average, 50-60 Z-series of $0.25 \mu \mathrm{m}$ were merged for analysis. The measurements were done by using NeuronJ (http://www.imagescience.org/meijering/software/ neuronj/).

NeuronJ is an ImageJ plugin module developed for tracing and quantification of elongated structures in two-dimensional images, in particular neurites in fluorescence microscopy images.

Morphological analysis of new mature neurons. Following retrovirus injection, the dendritic length and branching of 5-week-old $\mathrm{GFP}^{+}$new granule cells ( $n=15$ /group) were analyzed using the Leica DM4000 microscope with $20 \times$ water objective and a digital zoom of 2 (1024 $\times 1024$ pixel). On average, $50-70$ pictures with $0.5 \mu \mathrm{m}$ steps were merged for analyses. High-magnification pictures for spine density analysis were also taken using the Leica DM4000 microscope with $63 \times$ water objective and a digital zoom of $6(512 \times 512$ pixel $)$. On average, $100-130$ pictures of $0.120 \mu \mathrm{m}$ steps were merged for analysis. The autofluorescence of the labeled neurons was sufficiently strong so that anti-GFP staining was unnecessary. Z-stacks were deconvoluted, a process that filters the signal to improve the clarity of images by increasing resolution, removing outof-focus blur and eliminating noise, using the open source Huygens remote manager (http:// hrm.sourceforge.net/). Three-dimensional reconstructions of deconvoluted z-stacks were performed with Imaris 6.1 (Bitplane). After three-dimensional reconstructions, Scholl analysis, in which intersections between dendrites and concentric circles were counted, each one with a $10 \mu \mathrm{m}$ increment from the previous and centered at the soma, to determine the total dendrite length and branching density, or spine classification (stubby, long-thin and mushroom according to the original classification of Peters and Kaiserman-Abramof, 1970) along $40 \mu \mathrm{m}$ segments ( $n=50 /$ group) were done using the aforementioned software and its MatLab extensions (ImarisXT). Because spine density increases proportionally to the distance from the cell body, for each $\mathrm{GFP}^{+}$neuron used in the Scholl analysis, one to two dendritic segments were analyzed in the medial and external part of the outer ML, respectively.

Image analysis. All images were subjected to the following transformations: color pictures were first converted to grayscale images (8-bit), and the resulting images were then further adjusted to black and white by defining a grayscale cutoff point (threshold), and finally, all pictures within each experimental group were adjusted to the same threshold to allow for comparison of results. Quantifications of diffuse plaque load (6E10 staining), compact plaque burden (ThioS), and cerebral amyloid angiopathy (CAA) measured in the ThioS staining, were performed as described elsewhere (Wilcock et al., 2006). Briefly, ImageJ was used for measuring the area fraction ( $\%$ area), defined as the area positive for the staining in a constant and determined area, in cortex, hippocampus, and thalamus of both hemispheres. Similarly, ImageJ was used to quantify $\mathrm{Ibal}^{+}$immunoreactivity: in the dentate gyrus, the number of Ibal ${ }^{+}$cells was electronically counted, whereas in broader cerebral regions, e.g., 

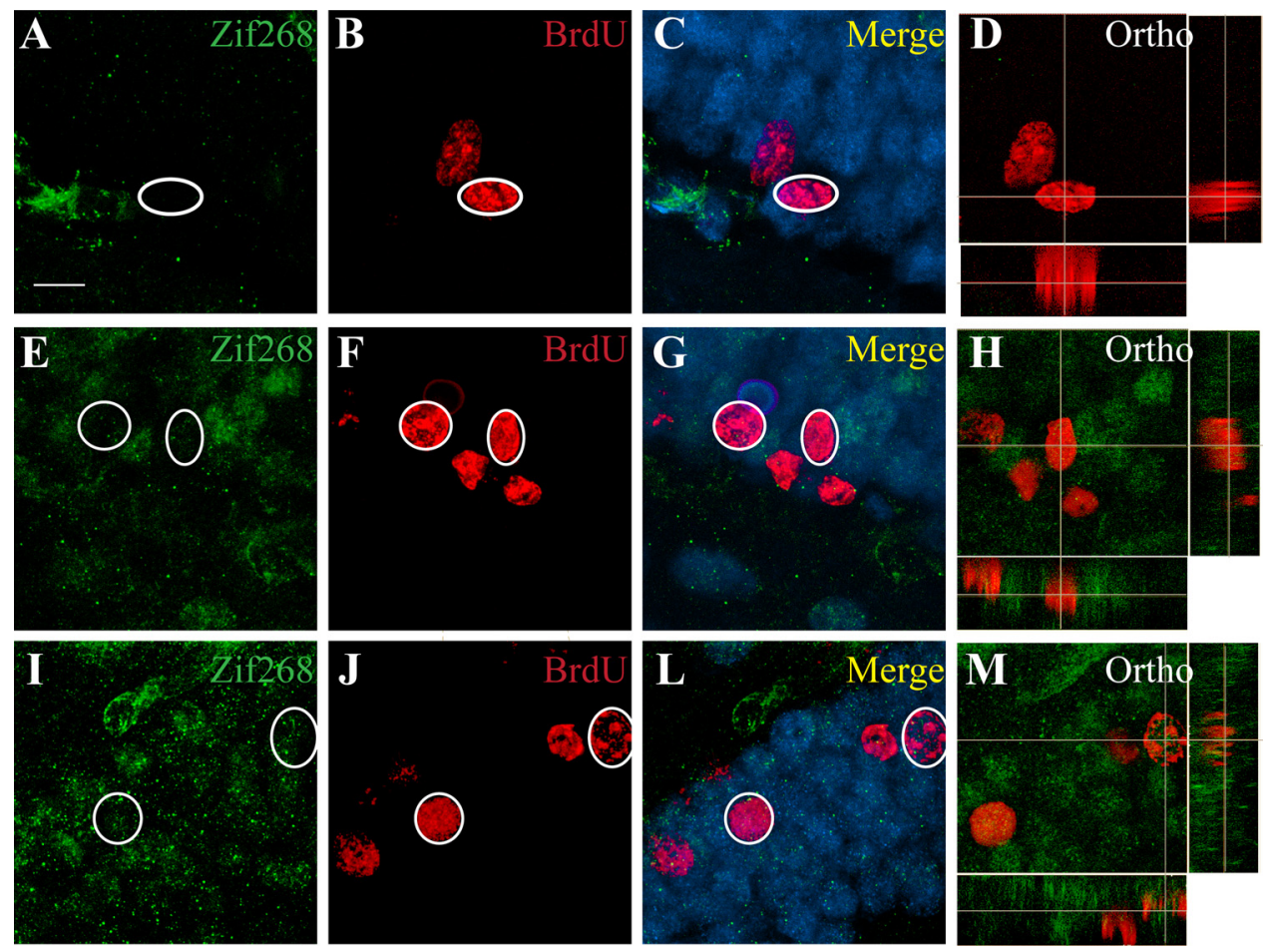

Figure 3. Newborn BrdU ${ }^{+}$neurons expressed the activity-dependent immediate early gene Zif268 during A $\beta$ immunotherapy as a sign of functional integration in pre-existing hippocampal synaptic circuits. Immunohistochemical stainings for the immediate-early gene product Zif268 (green), BrdU ${ }^{+}$nuclei (red), NeuN ${ }^{+}$neuronal nuclei (blue), overlay of the three channels (merge), and confocal orthogonal projections of merged Zif268 and BrdU images of selected granular neurons (ortho). A-D, Background expression of Zif268 in untreated APP/PS1 control mice without exposure to novel object stimulation: absent localization of Zif268 in nuclei of BrdU ${ }^{+}$granular neurons. $\boldsymbol{E}-\boldsymbol{H}$, Presence of Zif 268 in BrdU ${ }^{+}$nuclei of granular neurons within the SGZ/GCL in response to novel object exposure in vehicle-treated APP/PS1 mice. I-M, Presence of Zif268 in BrdU ${ }^{+}$nuclei of granular neurons within the SGZ/GCL during A $\beta$ immunotherapy and in response to novel object exposure. Circles depict selected BrdU ${ }^{+}$cells to facilitate their identification in the Zif268 staining. Scale bar: $\boldsymbol{A}, 10 \mu \mathrm{m}$.

lateral septal nuclei, fornix, and thalamus, the area fraction positive for Ibal staining was evaluated. The same analysis was used to quantify $\mathrm{CD} 11 \mathrm{~b}^{+}$areas in the hippocampus and septum as a measure of microglia activation. Assessment of the SYN levels was performed in the frontal neocortex and the hippocampal outer ML (Buttini et al., 2005; Priller et al., 2006). For each zone of interest, four confocal images were taken at magnification $63 \times$ in water with digital zoom 2, with z-stacks of 0.25 $\mu \mathrm{m}$. After maximum intensity projection of $\mathrm{z}$-stacks, the digitized images were analyzed for the signal intensity (average pixel intensity) of SYNlabeled structures by using ImageJ. For the histological analysis of the colocalization of cellular prion protein $\left(\mathrm{PrP}^{\mathrm{c}}\right)$ on dendrites of GFP ${ }^{+}$ newly born neurons, high-magnification stacks $(63 \times \mathrm{z} 8 ; 512 \times 512$ pixel; $0.16 z$-step) were analyzed by using ColocImaris software. This software specifically identifies voxels that are positive in both fluorescent channels, thereby dramatically reducing artifacts generated by overlays in z-levels.

$A \beta$ ELISA. Blood was withdrawn by heart puncture after deep anesthesia with ketamin/xylazine directly before perfusion and separated from erythrocytes by centrifugation. Plasma $A \beta_{1-42}$ was measured with the INNOTEST $\beta$-Amyloid (1-42) ELISA kit (Innogenetics) using the "high sensitivity" conjugate.

Statistical analyses. Comparisons between animal groups were performed using unpaired Student's $t$ test or one-way ANOVA, followed by Bonferroni's or Fisher's least significant difference post hoc tests. Data are presented as mean \pm SEM. Differences are considered significant at $p<$ 0.05. Calculations were made with Statview 5.0.

\section{Results}

Passive $A \boldsymbol{\beta}$ immunotherapy attenuated $\boldsymbol{\beta}$-amyloid pathology in APP/PS1-transgenic mice

After 3.5 months of treatment of 8-9-month-old doubly transgenic APP/PS1 mice with weekly i.p. injections of $\alpha$-A $\beta$, the highest accumulation of antibody was present in septum, fornix, and thalamus, as indicated by specific Cy3 anti-mouse IgG antibody staining (Fig. $1 A, B$ ). Antibody was also detected at lower concentrations within the hippocampus. The reasons for differences in antibody concentrations throughout the brains may include region-specific variations of extraction rates or varying amounts of CAA influencing both delivery and extraction rates of the antibody. Another possibility is a concentration gradient of antibody surrounding potential sites of entry into the brain, including the choroid plexus and the lateral ventricles. Fixation artifacts are likely excluded, because all brains were perfused with fixative before immunohistochemical analyses. In general, the antibody was associated with amyloid deposits, if present.

At $\sim 1$ year of age, the APP/PS1 mice treated with the control antibody presented severe $\beta$-amyloid deposits throughout their brains including the dentate gyrus as well as some deposits in the GCL. In addition, these mice developed CAA in cortex and thalamus. Although the antibody treatment did not change the 6E10immunopositive $\mathrm{A} \beta$ burden (data not shown), the amount of $\beta$-amyloid plaques detected by ThioS staining in the whole brain was significantly reduced by $37.8 \%$ in $\alpha$-A $\beta$ compared with ct ab-treated mice (APP/PS1 + ct ab: $1.75 \pm 0.16$ vs APP/PS $1+\alpha-$ $\mathrm{A} \beta: 1.14 \pm 0.14 \%$ area; $p<0.05$ ) (Fig. $1 C, D$ ). In the hippocampus, the area fraction covered with ThioS $^{+} \beta$-amyloid plaques in antibody-treated APP/PS1 mice was $>60 \%$ lower, from $1.32 \pm 0.29 \%$ in vehicle-treated APP/PS1 animals to $0.48 \pm$ $0.21 \%(p=0.05)$ in $\alpha$-A $\beta$-treated mice. Progressive accumulation of $\beta$-amyloid in the vicinity of blood vessels can result in microhemorrhages, and some studies have linked immunotherapy to an initial increase in CAA and microhemorrhages (Pfeifer et al., 2002; Wilcock et al., 2004a; Racke et al., 2005), followed by 

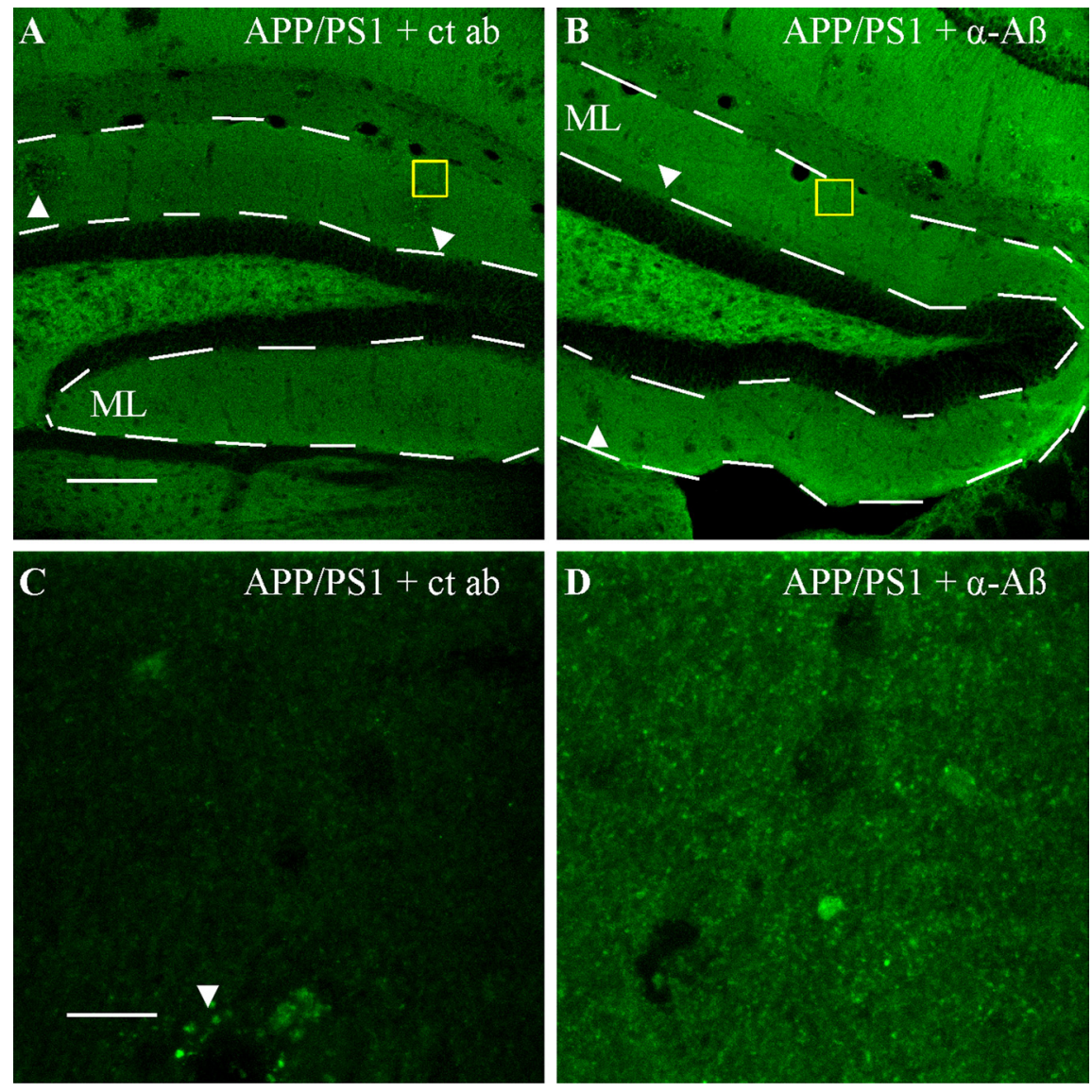

Figure 4. $A \beta$ immunotherapy increased the number of SYN-positive boutons in the ML of the hippocampus. $A, B, S Y N$-positive synapses in the hippocampal outer ML from controls (ct $a b ; \boldsymbol{A})$ and $A \beta$ immunotherapy-treated APP/PS1 mice $(\boldsymbol{B})$. Dotted lines depict the area analyzed stereologically for quantification of SYN-positive boutons. Arrowheads show the presence of $\beta$-amyloid plaques. $\boldsymbol{C}, \boldsymbol{D}$, High magnification details of the yellow squares in $\boldsymbol{A}$ and $\boldsymbol{B}$, respectively. The arrowhead in $\boldsymbol{C}$ depicts dystrophic boutons around a $\beta$-amyloid plaque. Stereological quantification of SYN-positive boutons in the ML revealed higher SYN levels in A $\beta$ immunotherapy-treated mice (APP/PS1 $+c t a b: 1.4 \pm 0.3$ vs APP/PS1 $+\alpha-A \beta: 2.8 \pm 0.2$ SYN $^{+}$boutons $\left(\times 10^{6}\right) ; p<0.01$; unpaired $t$ test). Scale bars: $\boldsymbol{A}, 120 \mu \mathrm{m} ; \boldsymbol{C}, 20 \mu \mathrm{m}$.

Table 2. Effects of $\boldsymbol{A} \boldsymbol{\beta}$ immunotherapy on cell genesis in dentate gyrus of 4 month-old non-tg, wild-type mice

\begin{tabular}{llc}
\hline Staining & Vehicle & $A \beta$ Immunotherapy \\
\hline BrdU/NeuN & $2466 \pm 260$ & $2231 \pm 657$ \\
BrdU/S100 $\beta$ & $29.5 \pm 21$ & $61 \pm 52$ \\
PSA-NCAM & $5698 \pm 1689$ & $5702 \pm 681$ \\
PCNA & $49.2 \pm 6.4$ & $38.4 \pm 4.8$ \\
GFAP & $8797 \pm 1964$ & $7433 \pm 1194$ \\
Iba1 & $3097 \pm 497$ & $3818 \pm 355$ \\
CD11b & 0 & 0 \\
\hline
\end{tabular}

Markers: BrdU/NeuN and PSA-NCAM for neurogenesis; BrdU/S100 $\beta$ for gliogenesis; PCNA for cell proliferation; and GFAP, Iba1, and CD11b for neuroinflammation. Values represent stereological cell counts and are means $\pm S E M$; $n=5$ (vehicle) and $n=4$ (A $\beta$ immunotherapy). No significant differences between groups were observed.

decrease during longer treatment periods (Schroeter et al., 2008). To exclude that the $\alpha$-A $\beta$ antibody treatment used here decreased parenchymal $\mathrm{A} \beta$ plaques but increased vascular $\mathrm{A} \beta$ deposits, we quantified CAA visualized by ThioS staining. However, no differences were detected between treatment and control groups (APP/PS $1+c t$ ab: $0.21 \pm 0.09$ vs APP/PS $1+\alpha-\mathrm{A} \beta$ : $0.17 \pm$ $0.09 \%$ area). The presence of microhemorrhages was detected by Prussian blue staining of hemosiderin. We observed microhemorrhages in $26 \%$ of the immunotherapy-treated APP/PS1- transgenic mice compared with $60 \%$ in ct ab-treated mice $\left(\chi^{2}:\right.$ NS) indicating the absence of increased microhemorrhages during $A \beta$ immunotherapy in our experimental setting. Reductions in $\beta$-amyloid plaque load were not accompanied by increased plasma levels of $\mathrm{A} \beta_{42}$ (APP/ PS1+ct ab: $1413.5 \pm 96.6 \mathrm{pg} / \mathrm{ml}$ vs APP/ PS1 $+\alpha-\mathrm{A} \beta: 1753 \pm 193.9 \mathrm{pg} / \mathrm{ml})$. To explore whether microglia could be involved in the reduction of $\beta$-amyloid plaques (Schenk et al., 1999), we evaluated the morphology and counted numbers of Iba1-positive cells. The $\alpha$-A $\beta$ - and ct abtreated mice showed similar numbers of $\mathrm{Ibal}^{+}$cells in the dentate gyrus (SGZ/GCL: $\mathrm{APP} / \mathrm{PS} 1+\mathrm{ctab}: 50.5 \pm 8.6$ vs APP/PS1 $+\alpha-$ $\mathrm{A} \beta: 57.3 \pm 6.4$ cells; hilus: APP/PS1 + ct ab: $50.8 \pm 14.4$ vs $\mathrm{APP} / \mathrm{PS} 1+\alpha-\mathrm{A} \beta: 55.9 \pm 7$ cells; septum-fornix-thalamus: APP/PS1+ ct ab: $7.4 \pm 1.02$ vs APP/PS1 $+\alpha-\mathrm{A} \beta$ : $8.9 \pm$ $1.06 \%$ area). There was no difference between the groups in the percentage of ramified-, intermediate-, amoeboid- or round-shaped Iba1 ${ }^{+}$microglia in the dentate gyrus or in the septum (Table 1). Furthermore, measurement of areas in the hippocampus and in the septum immunoreactive $\left(\mathrm{CD}_{11 \mathrm{~b}}{ }^{+}\right)$for activated microglia did not reveal any differences between groups (Table 1). Microglia can increase their proliferation rate during changes in activation state, but numbers of $\mathrm{BrdU}^{+} /$ $\mathrm{Ibal}^{+}$cells in the SGZ/GCL did not differ between $\alpha$-A $\beta$ and ct ab-treated mice (APP/ PS1 + ct ab: $20.2 \pm 2.1$ vs APP/PS1 $+\alpha-\mathrm{A} \beta$ : $21.6 \pm 2.7)$. Also, no significant differences were observed in SGZ/GCL or hilar volumes (SGZ/GCL: APP/PS1+ct ab: $2.6 \pm 0.6$ vs $\mathrm{APP} / \mathrm{PS} 1+\alpha-\mathrm{A} \beta: 3.6 \pm 0.2 \mathrm{~mm}^{3}$; hilus: $\mathrm{APP} / \mathrm{PS} 1+\mathrm{ctab}: 3.3 \pm 0.2 \mathrm{vs}$ $\mathrm{APP} / \mathrm{PS} 1+\alpha-\mathrm{A} \beta: 3.4 \pm 0.2 \mathrm{~mm}^{3}$ ).

\section{Passive $\mathrm{A} \boldsymbol{\beta}$ immunotherapy increased neurogenesis and dendritic arborization of new immature neurons in APP/PS1-transgenic mice}

In the APP/PS1 mice used in these experiments, the pathology associates with $\sim 50 \%$ more proliferating cells $\left(\mathrm{p}-\mathrm{H} 3^{+}\right.$and $\mathrm{BrdU}^{+}$) than non-tg controls. However, in the same animals, this initial increase does not result in higher numbers of mature $\left(\mathrm{BrdU}^{+} / \mathrm{NeuN}^{+}\right)$nor immature (PSA-NCAM + ) neurons, suggesting that the progenitors may not survive the $\mathrm{A} \beta$-related toxicity (B. Biscaro, unpublished observations; Chen et al., 2008). We first tested whether the antibody-mediated reduction in $\beta$-amyloid pathology had reversed these impairments of neurogenesis. Interestingly, both the numbers of $\mathrm{BrdU}^{+} / \mathrm{NeuN}^{+}$new mature neurons (APP/PS1+ct ab: $306 \pm 31$ vs APP/PS1 $+\alpha-\mathrm{A} \beta$ : $452 \pm 42$ cells; $p<0.05)$ and PSA-NCAM ${ }^{+}$young neurons $(\mathrm{APP} / \mathrm{PS} 1+\mathrm{ct}$ ab: $219 \pm 79$ vs APP/PS1 $\alpha-\mathrm{A} \beta: 842 \pm 275$ cells; $p=0.06)$ were higher in the $\alpha$-A $\beta$ - compared with the ct abtreated APP/PS1 mice. Moreover, the PSA-NCAM ${ }^{+}$neurons in the $\alpha$-A $\beta$-treated APP/PS1 mice had higher dendritic complexity with more and longer dendrites (number of dendrites per cell: $\mathrm{APP} / \mathrm{PS} 1+$ ct ab: $2.45 \pm 0.3$ vs APP/PS1 $+\alpha-\mathrm{A} \beta: 4 \pm 0.4, p<0.01$; 

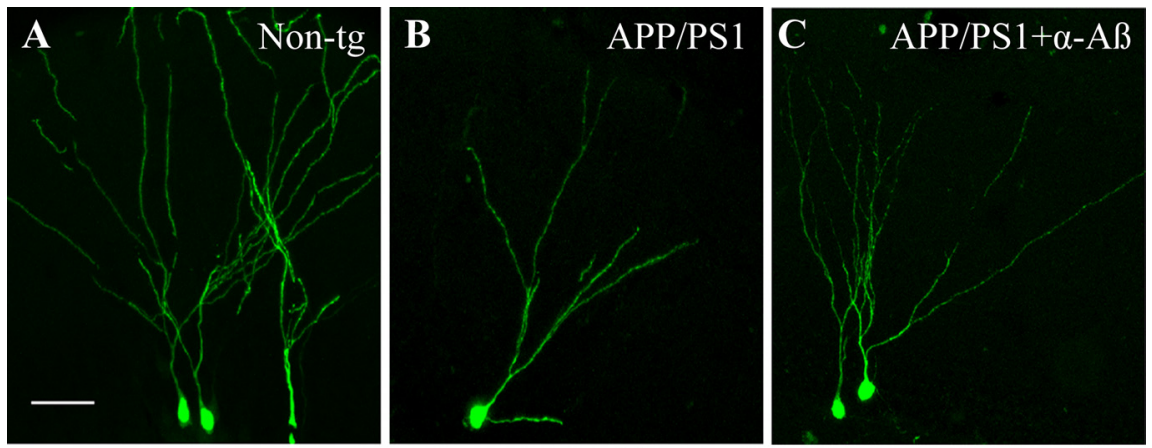

D
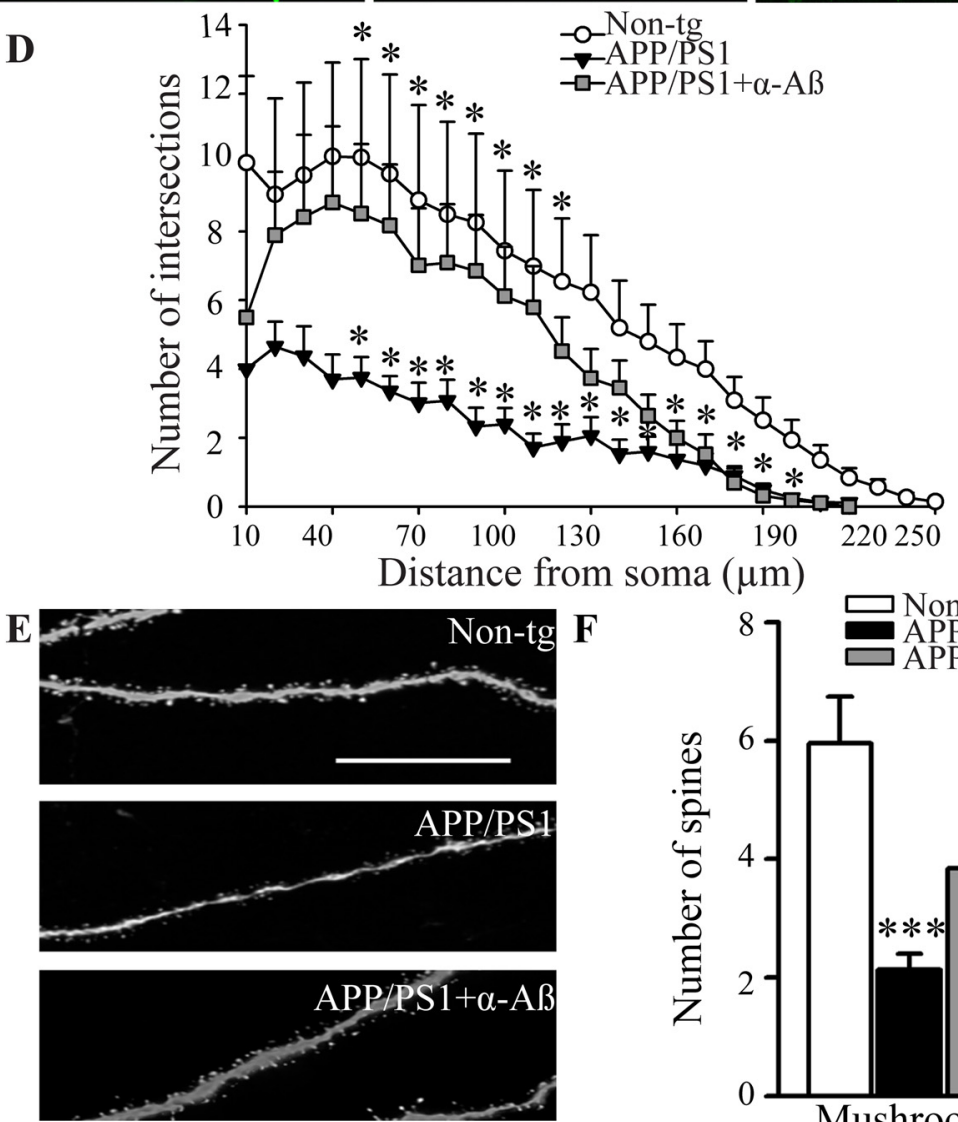

G
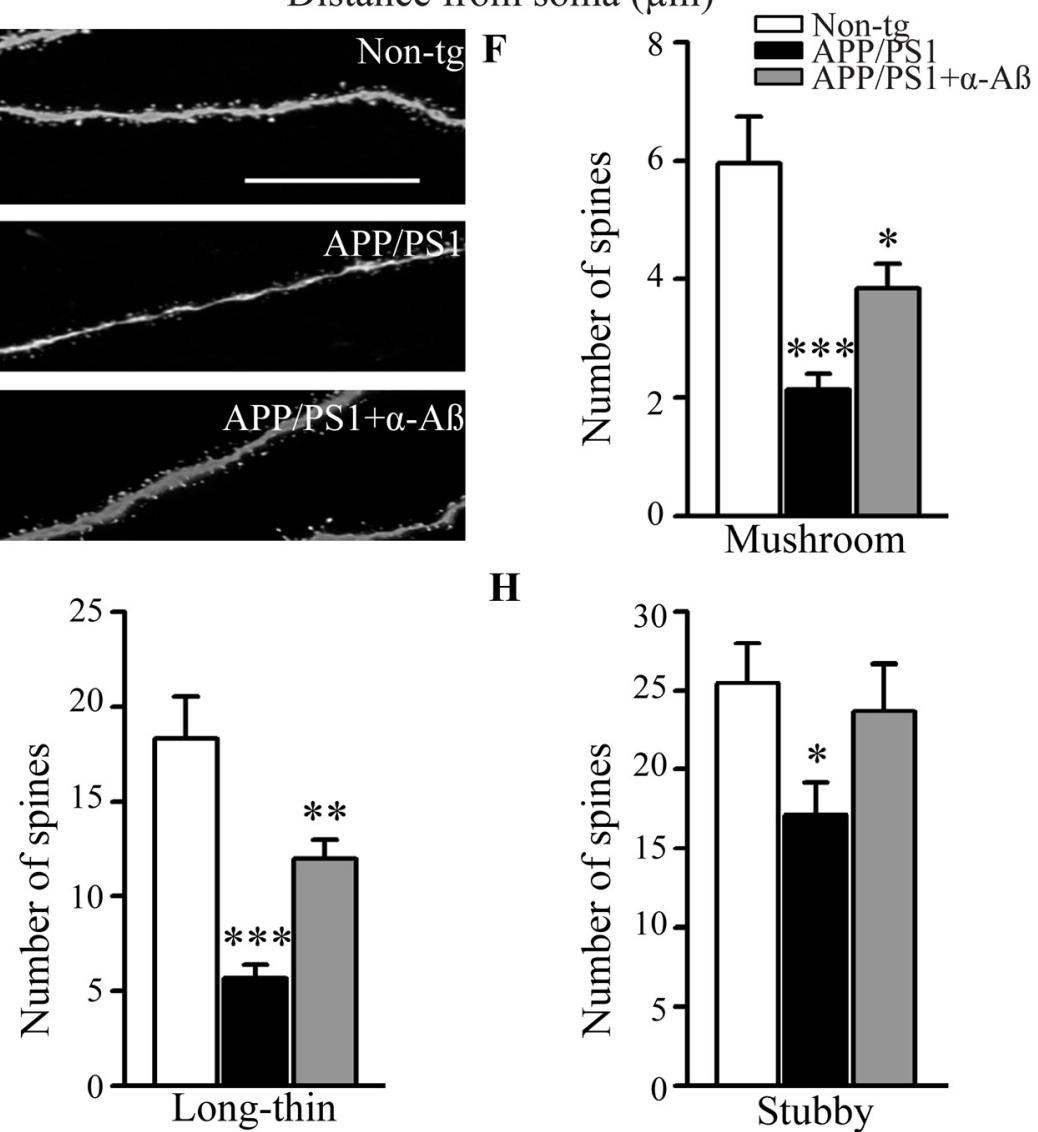

H

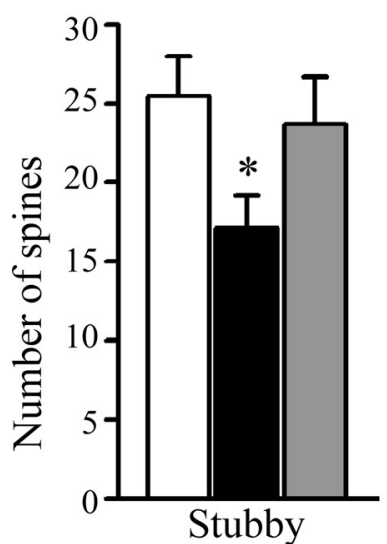

Figure 5. $A \beta$ immunotherapy increased dendritic branching and spine densities of mature retrovirally labeled newly born neurons. A-C, Representative confocal pictures of GFP ${ }^{+}$mature new neurons in the three groups of the study. Scale bar, $60 \mu \mathrm{m}$. $D$, Scholl analysis of new mature granule cells labeled with retrovirus expressing GFP revealed lower dendritic complexity in APP/PS1 mice compared with non-tg wild-type mice and restored dendritic complexity in APP/PS1 mice during A $\beta$ immunotherapy compared with vehicle-treated APP/PS1 mice. The graph represents the mean number of intersections between dendrites and concentric radii, centered at the cell body, as a function of distance from the soma; $n=15$ cells/group. Error bars represent SEM

and length of dendrites: APP/PS1 $+c t$ ab: $54.4 \pm 7$ vs APP/PS $1+\alpha-\mathrm{A} \beta: 85.5 \pm 10$ $\mu \mathrm{m}, p<0.01$ ) (Fig. $2 A-D$ ). The number of $\mathrm{BrdU}^{+} / \mathrm{S} 100 \beta^{+}$astrocytes did not differ between the groups (APP/PS1 + ct ab: $56 \pm 12.13$ vs $\mathrm{APP} / \mathrm{PS} 1+\alpha-\mathrm{A} \beta: 43 \pm$ 12.72). Also the numbers of $\mathrm{p}-\mathrm{H} 3^{+}$and $\mathrm{BrdU}^{+}$, proliferating cells in the SGZ/ GCL were similar in the two groups (APP/ PS1+ct ab: $174.4 \pm 92$ vs APP/PS1 $+\alpha-$ $\mathrm{A} \beta: 210.3 \pm 45.4 \mathrm{p}-\mathrm{H}^{+}$cells and APP/ PS1+ct ab: $547.2 \pm 57.5$ vs APP/PS1 $+\alpha-$ $\mathrm{A} \beta: 676.6 \pm 83.4 \mathrm{BrdU}^{+}$cells). Synaptic activity in the dentate gyrus induces robust expression of the immediate early gene Zif268 (or Erg-1), which is essential for the formation of long-term memories (Jones et al., 2001). If not exposed to stimulation such as novel environment or LTP, Zif268 is not constitutively transcribed in the GCL (Davis et al., 2003; Bruel-Jungerman et al., 2006). We analyzed Zif268 expression in the SGZ/GCL following a physiological stimulus induced by a novel object ("activation") (Fig. 3). Without exposure to the activation stimulus, there was no Zif268 expression in APP/PS1 mice (Fig. $3 A-D$ ). The activation stimulus induced Zif268 expression throughout the neuronal population in the SGZ/GCL both in vehicle-treated (Fig. $3 E-H)$ and $A \beta$ immunotherapy-treated mice (Fig. 3I-L). We established that also new mature neurons in $\mathrm{A} \beta$ immunotherapytreated mice responded to the activation stimulus as a sign of functional integration by showing stimulus-evoked Zif268 expression in $\mathrm{BrdU}^{+} / \mathrm{NeuN}^{+}$cells (Fig. 3I-L).

Both active and passive $\mathrm{A} \beta$-immunizations were reported to prevent synaptic degeneration in the frontal cortex and hippocampus of transgenic mice expressing APP mutants (Buttini et al., 2005). Consistent with these findings, $\alpha$-A $\beta$-treated mice showed increased numbers of SYN-positive

\footnotetext{
$* p<0.05$ non-tg versus APP/PS1, and APP/PS1 versus APP/ PS1 treated with $\alpha$-A $\beta$.E, Representative high-magnification segments from dendrites of new mature neurons in non- $\mathrm{tg}$, vehicle-treated APP/PS1, and $\alpha$-A $\beta$-treated APP/PS1 mice. Scale bar, $10 \mu \mathrm{m}$. $\boldsymbol{F}-\boldsymbol{H}$, Computer-assisted classification of spines along $40 \mu \mathrm{m}$ segments detected differences in the number of mushroom, long-thin, and stubby spines. $\boldsymbol{F}$, Significant reduction of numbers of mushroom spines in APP/PS1 compared with non-tg mice and significant rescue during $A \beta$ immunotherapy. $\mathbf{G}$, Significant reduction of numbers of longthin spines in APP/PS1 compared with non-tg mice and significant rescue during $A \beta$ immunotherapy. $\boldsymbol{H}$, Significant reduction of numbers of stubby spines in APP/PS1 compared with non-tg mice and a trend ( $p=0.07)$ toward rescue during $A \beta$ immunotherapy. $N=50$ segments/group. Error bars represent SEM $* p<0.05, * * p<0.01, * * * p<0.001$. ANOVA, followed by Bonferroni post hoc tests.
} 

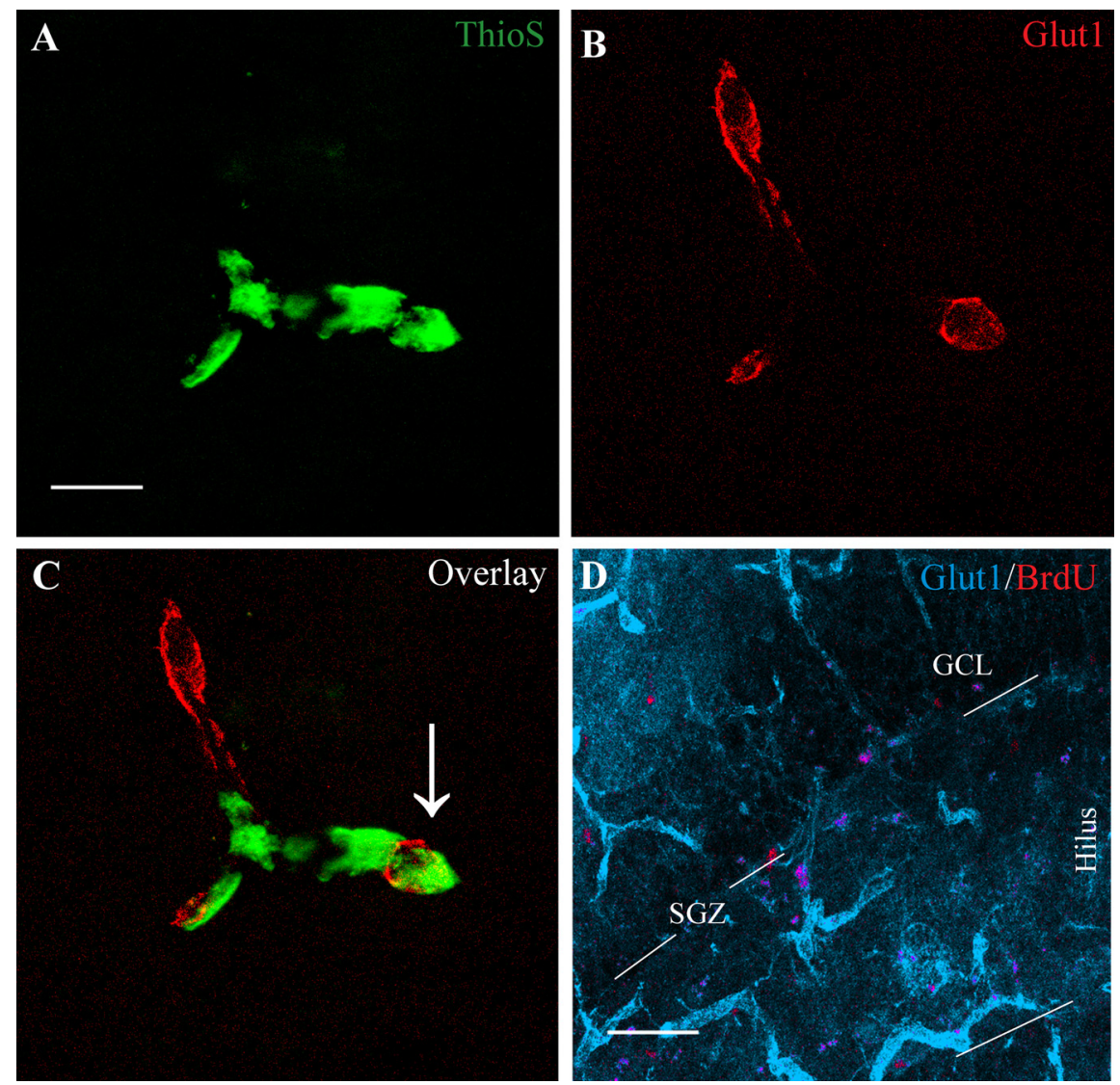

Figure 6. $A \beta$ immunotherapy increased angiogenesis in the dentate gyrus. Stereological estimation of the number of blood vessels indicated significant increases in the number of blood vessels in APP/PS1 mice during A $\beta$ immunotherapy (APP/PS1 + $c t$ ab: $5991 \pm 384$ vs APP/PS1 $+\alpha-A \beta: 8978 \pm 766$ blood vessels; $p<0.01$; unpaired $t$ test). $A, B$, Confocal images of Thio ${ }^{+}{ }^{+}$-A $\beta$-deposits along the wall of blood vessels in the cortex. $C$, Disruption of Glut1 expression in the presence of congophilic amyloid angiopathy. Arrow depicts colocalization of $A \beta$ with Glut1, excluding the possibility that Glut1 was present but not detected because of epitope-masking by $\beta$-amyloid D, Glut1-stained blood vessels (blue) and BrdU (red) in the dentate gyrus: many BrdU ${ }^{+}$cells are located in the vicinity ofblood vessels. Glut1 receptor is expressed at highest levels in the endothelial cells of barrier tissues such as the blood-brain barrier. Dotted lines in $A$ depict SGZ Scale bars: $A, 40 \mu \mathrm{m} ; \boldsymbol{D}, 70 \mu \mathrm{m}$.

boutons detected by stereological counting in the ML of the dentate gyrus, in which granule cells extend their dendrites toward the perforant path (APP/PS1+ct ab: $1.4 \pm 0.3$ vs APP/PS1 $+\alpha-\mathrm{A} \beta: 2.8 \pm 0.2 \mathrm{SYN}^{+}$ boutons $\left(\times 10^{6}\right), p<0.01$ ) (Fig. $\left.4 A-D\right)$. Also, computer-assisted analysis of SYN intensity in the ML revealed a significant increase following the $\mathrm{A} \beta$ immunotherapy (APP/PS1 + ct ab: $21.8 \pm 2.0 \mathrm{vs}$ $\mathrm{APP} / \mathrm{PS} 1+\alpha-\mathrm{A} \beta: 35.8 \pm 3.0$ staining intensity; $p<0.05)$.

To exclude nonspecific effects of the $\mathrm{A} \beta$ immunotherapy on neurogenesis, we administered the antibody to 4 months old non-tg wild-type mice. As expected, the numbers of new cells were substantially higher than in the older mice. The $\mathrm{A} \beta$ immunotherapy did not induce any significant changes in numbers of proliferating or differentiating cells in wild-type mice (Table 2). These data indicate that binding of the antibody to human $\mathrm{A} \beta$ aggregates, rather than nonspecific effects of IgG2, mediated the effects of $A \beta$ immunotherapy on neurogenesis in the dentate gyrus. Likewise, quantification in the dentate gyri of markers for gliogenesis, proliferation, and neuroinflammation did not reveal any differences between antibody and vehicle treatments of non-tg wild-type mice (Table 2).

Passive $A \boldsymbol{\beta}$ immunotherapy restored dendritic branching and spine density and morphology of new mature neurons in APP/PS1-transgenic mice

To investigate whether $A \beta$ immunotherapy affects the dendritic morphology of the new granule cells also when they have matured, we repeated the $\alpha-\mathrm{A} \beta$ treatment in mice that received retroviral injections into the dentate gyrus to label dividing cells with GFP. The GFP ${ }^{+}$granule cells were analyzed 5 weeks after the injection, a survival time considered to be sufficient for the newly born neurons to mature (van Praag et al., 2002; Zhao et al., 2006). We observed that the dendritic arborizations of the $\mathrm{GFP}^{+}$, new, and mature granule cells were significantly fewer in dentate gyri of vehicletreated APP/PS1 mice, whereas the numbers in $\alpha$-A $\beta$ antibody-treated mice resembled those of new neurons born in non-tg mice (Fig. 5A-D). Spines are the principal sites of excitatory synaptic transmission and can be classified according to their shapes and appearance. We classified spines as proposed by Peters and Kaiserman-Abramof (1970). "Long-thin" spines have a total length greater than the neck diameter; "stubby" spines are short and wide, whereas "mushroom" spines have a thick neck and a large irregular head. We found significant reduction in all three spine subgroups on $\mathrm{GFP}^{+}$cells in $\mathrm{ct}$ abtreated APP/PS1 mice compared with non-tg mice. The $\alpha$-A $\beta$ treatment reversed this loss of spines by $\sim 50 \%$ for long-thin, stubby, and mushroom spines (Fig. $5 E-H$ ).

\section{Passive $A \boldsymbol{\beta}$ immunotherapy increased angiogenesis in dentate gyrus of APP/PS1-transgenic mice}

To explore the previously described close links between neurogenesis and angiogenesis in the stem cell niche (Palmer et al., 2000), we determined whether the enhancement of neurogenesis in APP/PS1 treated with passive A $\beta$ immunotherapy was associated with increased angiogenesis. Following the treatment, many BrdU ${ }^{+}$cells were located adjacent to blood vessels, and numbers of blood vessels, quantified by endothelial stains for lectin and Glut1, were significantly higher in $\alpha$-A $\beta$-treated APP/PS1 mice compared with control antibody-treated mice (APP/PS1 $+\mathrm{ct}$ ab: $5991 \pm 384$ vs APP/PS1 $+\alpha$-A $\beta$ : $8978 \pm 766$ blood vessels; $p<$ 0.01 ) (Fig. 6D). Stereological estimation of vessel length detected a trend toward an increase following antibody treatment (APP/ PS1+ct ab: $0.17 \pm 0.03$ vs APP/PS $1+\alpha-\mathrm{A} \beta: 0.31 \pm 0.06 \mathrm{~m} ; p=$ 0.07). Combining the ThioS staining of CAA with the Glut1 staining of endothelial cells often showed disruption of Glut1 immunoreactivity in the presence of ThioS-stained CAA around vessels (Fig. $6 A-C)$, indicating that progressive accumulation of compact $\beta$-amyloid leads to the deterioration of endothelial tissues. Preventing or delaying this deposition by passive $A \beta$ immunotherapy may reverse this effect and result in higher numbers of blood vessels, as described above. Together, these findings indicate that passive immunotherapy can lead to increased angiogenesis as well as neurogenesis.

\section{Localization of cellular prion protein on dendrites of newly born neurons}

A possible role for $\operatorname{PrP}^{c}$ in mediating synaptic toxicity of $\mathrm{A} \beta$ oligomers was described recently (Lauren et al., 2009). To explore 
whether $\operatorname{PrP}^{\mathrm{c}}$ is present on retrovirus-labeled, $\mathrm{GFP}^{+}$new neurons, we analyzed colocalization of $\mathrm{PrP}^{\mathrm{c}}$ with GFP by using ColocImaris software on high-magnification images to specifically identify colocalized proteins and to exclude overlay artifacts. As expected, $\operatorname{PrP}^{\mathrm{c}}$ was present ubiquitously on cells throughout the brain. $\operatorname{PrP}^{\mathrm{c}}$ was also present, at equal levels compared with pre-existing brain cells, on the dendrites of retrovirus-labeled, $\mathrm{GFP}^{+}$newly born neurons. $\operatorname{PrP}^{\mathrm{c}}$ staining on dendrites of newly born neurons had a patchy appearance consistent with its known cellular distribution (Hantman and Perl, 2005), and $~ 5 \%$ of the analyzed dendritic surface of newly born neurons was costained for $\operatorname{PrP}^{\mathrm{c}}$ (Fig. 7). $\operatorname{PrP}^{\mathrm{c}}$ was present at equal levels on dendrites of newly born neurons in both non-tg, wild-type, and APP/PS1 mice, suggesting that the expression of the APP and PS1 transgenes under the control of the $\operatorname{PrP}^{\mathrm{c}}$ and PDGF $\beta$ promoters, respectively, did not affect the colocalization of $\mathrm{PrP}^{\mathrm{c}}$ with dendrites of newly born neurons. $\mathrm{A} \beta$ immunotherapy had no obvious effect on the colocalization of $\operatorname{PrP}^{\mathrm{c}}$ with dendrites of newly born neurons.

\section{Discussion}

The results of this study establish that reductions in compact $\beta$-amyloid plaque load in adult APP/PS1 doubly transgenic mice by passive $A \beta$ immunotherapy rescue impairments in adult hippocampal neurogenesis. Following $A \beta$ immunotherapy, more new neurons survived, and their morphological deficits were reversed. Although the untreated transgenic APP/PS1 mice exhibited abnormalities in dendritic branching and lower numbers of all spine subtypes in the new hippocampal neurons, the mice treated with $\mathrm{A} \beta$ immunotherapy had longer dendrites, and more complex dendritic arborization with restored stubby, mushroom, and long-thin spines. The morphology of the newly born hippocampal neurons in transgenic mice subjected to $\mathrm{A} \beta \mathrm{immu}$ notherapy resembled that in untreated non-tg mice consistent with the possibility of rescued synaptic structures. These results were likely related to the specific interaction of the antibody with human $\mathrm{A} \beta$ aggregates deposited in brains of APP/PS1 mice- - and possibly to the lowering of $\beta$-amyloid pathology-rather than to nonspecific effects of the antibody, as indicated by the absence of stimulated neurogenesis in the dentate gyrus of antibody-treated non-tg, wild-type mice.

The stimulation of neurogenesis and the improved dendrite and spine morphology of the new neurons could be related to a more favorable microenvironment created by antibodyrelated neutralizing events and the reduced neurotoxicity. In line with this interpretation, passive $\mathrm{A} \beta$-immunotherapy ameliorates synaptic deficits on already formed, mature hippocampal and cortical neurons (Buttini et al., 2005). Moreover, the formation of new hippocampal neurons in APP-transgenic mice is increased by active $A \beta$ vaccination (Becker et al., 2007). In these mice, preventive active vaccinations with $A \beta$-related antigens were initiated before the onset of $\beta$-amyloid plaque formation, and the immune response was then boosted $>8-9$ months. Compared with the study of Becker et al. (2007), we report here the following novel observations: First, we demonstrate that $\mathrm{A} \beta$-immunotherapy improves neurogenesis in adult animals with substantial pre-existing $\beta$-amyloid pathology, more closely resembling the stage of pathol- ogy in human patients with a clinical diagnosis of probable AD. Second, we show that active vaccination associated with stimulation of cellular immunity is not necessary to increase neurogenesis in vivo but that humoral immunity induced by passive antibody transfer is sufficient. Third, we provide the first experimental evidence that $A \beta$ immunotherapy not only enhances hippocampal neurogenesis but also reverses deficits in the morphological development of the new neurons. Because we found that the effects on neurogenesis were achieved in the presence of considerable amounts of $A \beta$ in the brain, our data indicate that already the initial phase of antibodymediated $\beta$-amyloid clearance is associated with beneficial therapeutic effects.

The involvement of adult hippocampal neurogenesis in learning and memory is still unclear, but a growing body of evidence supports a role of the new neurons in memory acquisition (Snyder et al., 2005; Kee et al., 2007; Jessberger et al., 2009). If the birth of new granule cells in the SGZ/GCL leads to their recruitment into preexisting neuronal circuits contributing to hippocampal functions related to learning (Kempermann, 2008), it is conceivable that the up-regulation of neurogenesis reported here may be related to the reversal of cognitive deficits. In support, restored behavior in transgenic mice treated with $\mathrm{A} \beta$ immunotherapy has been observed after both active vaccination and passive antibody transfer (Janus et al., 2000; Morgan et al., 2000; Dodart et al., 2002; Chen et al., 2007). We found that new granule cells exhibited expression of the activity-dependent immediate early gene Zif268 (Egr-1). Because Zif268 expression is up-regulated by neuronal activity, this result is consistent with functional integration of the new neurons into pre-existing neural circuitries.

Dendritic spines are the major sites for excitatory synaptic input. Although large stubby spines and mushroom spines are stable and required for the maintenance of synapses, small, longthin spines are unstable and thought to be required for memory acquisition (Kasai et al., 2003). The numbers of all types of dendritic spines were increased during $A \beta$ immunotherapy. Together with the longer dendrites and more ramified dendritic arborizations, these findings are indicative of better functional integration of the new neurons in treated compared with untreated transgenic mice. In support of this possibility, stereological estimation of SYN-positive boutons in the area in which the dendrites of the new neurons receive synaptic inputs from the 
perforant path, the dentate outer ML, revealed increases following $\mathrm{A} \beta$ immunotherapy. Spine densities as well as dendritic arborization and length of newly born neurons were already decreased in 4 -month-old APP/PS1 before the onset of $\beta$-amyloid plaque deposition in the dentate gyrus consistent with the possibility that smaller, oligomeric $\mathrm{A} \beta$ species mediated the impairment. As a corollary, the rescue during $A \beta$ immunotherapy may also be related to neutralization of oligomeric $\mathrm{A} \beta$ species by the antibody reacting with $\mathrm{A} \beta$ aggregates.

Our data also show that $\mathrm{A} \beta$ immunotherapy increased the numbers of blood vessels in APP/PS1 doubly transgenic mice compared with control-treated mice. More numerous blood vessels may be related to increased neurogenesis by creating niches for the new cells. It is known that increased angiogenesis can stimulate neurogenesis via vascular endothelial growth factor, and that it can be associated with improved functions. In addition, it has been suggested that angiogenesis links external stimuli including exercise or learning to neurogenesis (Jin et al., 2002; Cao et al., 2004; van Praag et al., 2005; Udo et al., 2008).

We obtained no evidence for changes in numbers or morphological phenotypes of $\mathrm{Iba}^{+}$microglia or in the expression of $\mathrm{CD} 11 \mathrm{~b}$ after 3.5 months of $\mathrm{A} \beta$ immunotherapy. This finding raises the possibility that microglia were either not activated further over levels in non-tg controls or that they were only transiently activated during immunotherapy and have returned to levels of control-treated transgenic mice after 3.5 months of treatment as described previously (Wilcock et al., 2004b; Dickstein et al., 2006). The fact that there were no significant changes in plasma $\mathrm{A} \beta_{42}$ in $\alpha$-A $\beta$-treated mice argues against a significant role of peripheral A $\beta$ sink in our experiments (DeMattos et al., 2001).

The mechanism linking $\mathrm{A} \beta$-related toxicity to impaired neurogenesis and to defective morphology of newly born neurons identified in our experiments is unknown. A possible role for $\operatorname{PrP}^{\mathrm{c}}$ in mediating $\mathrm{A} \beta$-related impairments of synaptic plasticity involves $\operatorname{PrP}^{\mathrm{c}}$ functions as a cell surface receptor that binds oligomeric $\mathrm{A} \beta$ aggregates to a domain of $\mathrm{PrP}^{\mathrm{c}}$ that is associated with neurodegeneration and with impaired hippocampal LTP in response to $\mathrm{A} \beta$ oligomer binding (Lauren et al., 2009). Interestingly, we found that $\operatorname{PrP}^{\mathrm{c}}$ was present on the dendrites of newly born neurons at approximately equal levels compared with preexisting brain cells, covering $5 \%$ of the dendritic surface of newly born neurons. Dendritic $\operatorname{PrP}^{\mathrm{c}}$ had a patchy appearance consistent with a possible presence of $\operatorname{PrP}^{c}$ on dendritic spines of the newly born neurons, which may explain the observed vulnerability of dendritic spines in our APP/PS1 mice as well as the recovery of spine density and dendritic morphology during $A \beta$ immunotherapy.

In conclusion, our study shows that passive $A \beta$ immunotherapy can restore hippocampal neurogenesis in APP/PS1-transgenic mice. In particular, $A \beta$ immunotherapy rescued the length and arborization of dendrites of newly born neurons and restored the density of mushroom and long-thin spines. The newly born neurons showed signs of functional activity indicated by expression of the immediate early gene Zif268 in $\mathrm{BrdU}^{+} / \mathrm{NeuN}^{+}$cells. $\mathrm{A} \beta$ immunotherapy increased the numbers of SYN-positive boutons, and it increased angiogenesis in APP/PS1 mice with pre-existing $\beta$-amyloid pathology. The presence of $\mathrm{PrP}^{\mathrm{c}}$ on the dendrites of $\mathrm{GFP}^{+}$newly born neurons provides suggestive evidence that it may mediate $\mathrm{A} \beta$-related toxicity in these cells. The rescued neurogenesis and morphological development of the newly born neurons constitute a novel mechanism that could explain part of the functional improvements during passive $\mathrm{A} \beta$ immunotherapy. Our findings provide the first evidence that antibody-related stimulation of endogenous stem cells and the development of their progeny, mediated through clearance or neutral- ization of the pathological microenvironment, may become a new therapeutic strategy for the rehabilitation of functions compromised by the toxicity of $\mathrm{A} \beta$-related peptides in $\mathrm{AD}$.

\section{References}

Abdipranoto A, Wu S, Stayte S, Vissel B (2008) The role of neurogenesis in neurodegenerative diseases and its implications for therapeutic development. CNS Neurol Disord Drug Targets 7:187-210.

Altman J, Das GD (1965) Autoradiographic and histological evidence of postnatal hippocampal neurogenesis in rats. J Comp Neurol 124:319-335.

Arvidsson A, Collin T, Kirik D, Kokaia Z, Lindvall O (2002) Neuronal replacement from endogenous precursors in the adult brain after stroke. Nat Med 8:963-970.

Bard F, Cannon C, Barbour R, Burke RL, Games D, Grajeda H, Guido T, Hu K, Huang J, Johnson-Wood K, Khan K, Kholodenko D, Lee M, Lieberburg I, Motter R, Nguyen M, Soriano F, Vasquez N, Weiss K, Welch B, Seubert P, Schenk D, Yednock T (2000) Peripherally administered antibodies against amyloid $\beta$-peptide enter the central nervous system and reduce pathology in a mouse model of Alzheimer disease. Nat Med 6:916-919.

Becker M, Lavie V, Solomon B (2007) Stimulation of endogenous neurogenesis by anti-EFRH immunization in a transgenic mouse model of Alzheimer's disease. Proc Natl Acad Sci U S A 104:1691-1696.

Beckmann AM, Wilce PA (1997) Egr transcription factors in the nervous system. Neurochem Int 31:477-510, discussion 517-476.

Bengzon J, Kokaia Z, Elmér E, Nanobashvili A, Kokaia M, Lindvall O (1997) Apoptosis and proliferation of dentate gyrus neurons after single and intermittent limbic seizures. Proc Natl Acad Sci U S A 94:10432-10437.

Bravo R, Macdonald-Bravo H (1987) Existence of two populations of cyclin/proliferating cell nuclear antigen during the cell cycle: association with DNA replication sites. J Cell Biol 105:1549-1554.

Bruel-Jungerman E, Davis S, Rampon C, Laroche S (2006) Long-term potentiation enhances neurogenesis in the adult dentate gyrus. J Neurosci 26:5888-5893.

Buttini M, Masliah E, Barbour R, Grajeda H, Motter R, Johnson-Wood K, Khan K, Seubert P, Freedman S, Schenk D, Games D (2005) $\beta$-Amyloid immunotherapy prevents synaptic degeneration in a mouse model of Alzheimer's disease. J Neurosci 25:9096-9101.

Cao L, Jiao X, Zuzga DS, Liu Y, Fong DM, Young D, During MJ (2004) VEGF links hippocampal activity with neurogenesis, learning and memory. Nat Genet 36:827-835.

Chen G, Chen KS, Kobayashi D, Barbour R, Motter R, Games D, Martin SJ, Morris RG (2007) Active $\beta$-amyloid immunization restores spatial learning in PDAPP mice displaying very low levels of $\beta$-amyloid. J Neurosci 27:2654-2662.

Chen Q, Nakajima A, Choi SH, Xiong X, Sisodia SS, Tang YP (2008) Adult neurogenesis is functionally associated with $\mathrm{AD}$-like neurodegeneration. Neurobiol Dis 29:316-326.

Curtis MA, Penney EB, Pearson AG, van Roon-Mom WM, Butterworth NJ, Dragunow M, Connor B, Faull RL (2003) Increased cell proliferation and neurogenesis in the adult human Huntington's disease brain. Proc Natl Acad Sci U S A 100:9023-9027.

Davis S, Bozon B, Laroche S (2003) How necessary is the activation of the immediate early gene zif268 in synaptic plasticity and learning? Behav Brain Res 142:17-30.

DeMattos RB, Bales KR, Cummins DJ, Dodart JC, Paul SM, Holtzman DM (2001) Peripheral anti-A $\beta$ antibody alters CNS and plasma $A \beta$ clearance and decreases brain $\mathrm{A} \beta$ burden in a mouse model of Alzheimer's disease. Proc Natl Acad Sci U S A 98:8850-8855.

Dickstein DL, Biron KE, Ujiie M, Pfeifer CG, Jeffries AR, Jefferies WA (2006) $\mathrm{A} \beta$ peptide immunization restores blood-brain barrier integrity in $\mathrm{Alz}$ heimer disease. FASEB J 20:426-433.

Dodart JC, Bales KR, Gannon KS, Greene SJ, DeMattos RB, Mathis C, DeLong CA, Wu S, Wu X, Holtzman DM, Paul SM (2002) Immunization reverses memory deficits without reducing brain $\mathrm{A} \beta$ burden in Alzheimer's disease model. Nat Neurosci 5:452-457.

Dolbeare F (1995) Bromodeoxyuridine: a diagnostic tool in biology and medicine. Part II. Oncology, chemotherapy and carcinogenesis. Histochem J 27:923-964.

Eriksson PS, Perfilieva E, Björk-Eriksson T, Alborn AM, Nordborg C, Peterson DA, Gage FH (1998) Neurogenesis in the adult human hippocampus. Nat Med 4:1313-1317. 
Ernst C, Christie BR (2006) Isolectin-IB 4 as a vascular stain for the study of adult neurogenesis. J Neurosci Methods 150:138-142.

Gundersen HJ, Jensen EB (1987) The efficiency of systematic sampling in stereology and its prediction. J Microsc 147:229-263.

Gundersen HJ, Bagger P, Bendtsen TF, Evans SM, Korbo L, Marcussen N, Møller A, Nielsen K, Nyengaard JR, Pakkenberg B, et al (1988) The new stereological tools: disector, fractionator, nucleator and point sampled intercepts and their use in pathological research and diagnosis. APMIS 96:857-881.

Guzowski JF, McNaughton BL, Barnes CA, Worley PF (1999) Environmentspecific expression of the immediate-early gene Arc in hippocampal neuronal ensembles. Nat Neurosci 2:1120-1124.

Haass C, Selkoe DJ (2007) Soluble protein oligomers in neurodegeneration: lessons from the Alzheimer's amyloid $\beta$-peptide. Nat Rev Mol Cell Biol 8:101-112.

Hantman AW, Perl ER (2005) Molecular and genetic features of a labeled class of spinal substantia gelatinosa neurons in a transgenic mouse. J Comp Neurol 492:90-100.

Hendzel MJ, Wei Y, Mancini MA, Van Hooser A, Ranalli T, Brinkley BR, Bazett-Jones DP, Allis CD (1997) Mitosis-specific phosphorylation of histone $\mathrm{H} 3$ initiates primarily within pericentromeric heterochromatin during G2 and spreads in an ordered fashion coincident with mitotic chromosome condensation. Chromosoma 106:348-360.

Hock C, Konietzko U, Streffer JR, Tracy J, Signorell A, Müller-Tillmanns B, Lemke U, Henke K, Moritz E, Garcia E, Wollmer MA, Umbricht D, de Quervain DJ, Hofmann M, Maddalena A, Papassotiropoulos A, Nitsch RM (2003) Antibodies against $\beta$-amyloid slow cognitive decline in Alzheimer's disease. Neuron 38:547-554.

Holcomb L, Gordon MN, McGowan E, Yu X, Benkovic S, Jantzen P, Wright K, Saad I, Mueller R, Morgan D, Sanders S, Zehr C, O'Campo K, Hardy J, Prada CM, Eckman C, Younkin S, Hsiao K, Duff K (1998) Accelerated Alzheimer-type phenotype in transgenic mice carrying both mutant amyloid precursor protein and presenilin 1 transgenes. Nat Med 4:97-100.

Holmes C, Boche D, Wilkinson D, Yadegarfar G, Hopkins V, Bayer A, Jones RW, Bullock R, Love S, Neal JW, Zotova E, Nicoll JA (2008) Long-term effects of Abeta42 immunisation in Alzheimer's disease: follow-up of a randomised, placebo-controlled phase I trial. Lancet 372:216-223.

Hsiao K, Chapman P, Nilsen S, Eckman C, Harigaya Y, Younkin S, Yang F, Cole G (1996) Correlative memory deficits, $A \beta$ elevation, and amyloid plaques in transgenic mice. Science 274:99-102.

Imai Y, Ibata I, Ito D, Ohsawa K, Kohsaka S (1996) A novel gene ibal in the major histocompatibility complex class III region encoding an EF hand protein expressed in a monocytic lineage. Biochem Biophys Res Commun 224:855-862.

Janus C, Pearson J, McLaurin J, Mathews PM, Jiang Y, Schmidt SD, Chishti MA, Horne P, Heslin D, French J, Mount HT, Nixon RA, Mercken M, Bergeron C, Fraser PE, St George-Hyslop P, Westaway D (2000) A $\beta$ peptide immunization reduces behavioural impairment and plaques in a model of Alzheimer's disease. Nature 408:979-982.

Jessberger S, Clark RE, Broadbent NJ, Clemenson GD, Jr., Consiglio A, Lie DC, Squire LR, Gage FH (2009) Dentate gyrus-specific knockdown of adult neurogenesis impairs spatial and object recognition memory in adult rats. Learn Mem 16:147-154.

Jin K, Zhu Y, Sun Y, Mao XO, Xie L, Greenberg DA (2002) Vascular endothelial growth factor (VEGF) stimulates neurogenesis in vitro and in vivo. Proc Natl Acad Sci U S A 99:11946-11950.

Jin K, Peel AL, Mao XO, Xie L, Cottrell BA, Henshall DC, Greenberg DA (2004) Increased hippocampal neurogenesis in Alzheimer's disease. Proc Natl Acad Sci U S A 101:343-347.

Jones MW, Errington ML, French PJ, Fine A, Bliss TV, Garel S, Charnay P, Bozon B, Laroche S, Davis S (2001) A requirement for the immediate early gene Zif268 in the expression of late LTP and long-term memories. Nat Neurosci 4:289-296.

Kasai H, Matsuzaki M, Noguchi J, Yasumatsu N, Nakahara H (2003) Structure-stability-function relationships of dendritic spines. Trends Neurosci $26: 360-368$.

Kee N, Teixeira CM, Wang AH, Frankland PW (2007) Preferential incorporation of adult-generated granule cells into spatial memory networks in the dentate gyrus. Nat Neurosci 10:355-362.

Kempermann G (2008) The neurogenic reserve hypothesis: what is adult hippocampal neurogenesis good for? Trends Neurosci 31:163-169.
Kempermann G, Kuhn HG, Gage FH (1997) More hippocampal neurons in adult mice living in an enriched environment. Nature 386:493-495.

Kobayashi DT, Chen KS (2005) Behavioral phenotypes of amyloid-based genetically modified mouse models of Alzheimer's disease. Genes Brain Behav 4:173-196.

Kuhn HG, Cooper-Kuhn CM, Boekhoorn K, Lucassen PJ (2007) Changes in neurogenesis in dementia and Alzheimer mouse models: are they functionally relevant? Eur Arch Psychiatry Clin Neurosci 257:281-289.

Kubik S, Miyashita T, Guzowski JF (2007) Using immediate-early genes to map hippocampal subregional functions. Learn Mem 14:758-770.

Larsen JO, Gundersen HJ, Nielsen J (1998) Global spatial sampling with isotropic virtual planes: estimators of length density and total length in thick, arbitrarily orientated sections. J Microsc 191:238-248.

Laurén J, Gimbel DA, Nygaard HB, Gilbert JW, Strittmatter SM (2009) Cellular prion protein mediates impairment of synaptic plasticity by amyloid- $\beta$ oligomers. Nature 457:1128-1132.

Lee GD, Aruna JH, Barrett PM, Lei DL, Ingram DK, Mouton PR (2005) Stereological analysis of microvascular parameters in a double transgenic model of Alzheimer's disease. Brain Res Bull 65:317-322.

Lesné S, Koh MT, Kotilinek L, Kayed R, Glabe CG, Yang A, Gallagher M, Ashe $\mathrm{KH}$ (2006) A specific amyloid- $\beta$ protein assembly in the brain impairs memory. Nature 440:352-357.

Li B, Yamamori H, Tatebayashi Y, Shafit-Zagardo B, Tanimukai H, Chen S, Iqbal K, Grundke-Iqbal I (2008) Failure of neuronal maturation in Alzheimer disease dentate gyrus. J Neuropathol Exp Neurol 67:78-84.

Lie DC, Song H, Colamarino SA, Ming GL, Gage FH (2004) Neurogenesis in the adult brain: new strategies for central nervous system diseases. Annu Rev Pharmacol Toxicol 44:399-421.

Marcello E, Epis R, Di Luca M (2008) Amyloid flirting with synaptic failure: towards a comprehensive view of Alzheimer's disease pathogenesis. Eur J Pharmacol 585:109-118.

Morgan D, Diamond DM, Gottschall PE, Ugen KE, Dickey C, Hardy J, Duff K, Jantzen P, DiCarlo G, Wilcock D, Connor K, Hatcher J, Hope C, Gordon M, Arendash GW (2000) A $\beta$ peptide vaccination prevents memory loss in an animal model of Alzheimer's disease. Nature 408:982-985.

Nicoll JA, Wilkinson D, Holmes C, Steart P, Markham H, Weller RO (2003) Neuropathology of human Alzheimer disease after immunization with amyloid- $\beta$ peptide: a case report. Nat Med 9:448-452.

Oddo S, Caccamo A, Shepherd JD, Murphy MP, Golde TE, Kayed R, Metherate R, Mattson MP, Akbari Y, LaFerla FM (2003) Triple-transgenic model of Alzheimer's disease with plaques and tangles: intracellular $A \beta$ and synaptic dysfunction. Neuron 39:409-421.

Palmer TD, Willhoite AR, Gage FH (2000) Vascular niche for adult hippocampal neurogenesis. J Comp Neurol 425:479-494.

Parent JM, Yu TW, Leibowitz RT, Geschwind DH, Sloviter RS, Lowenstein DH (1997) Dentate granule cell neurogenesis is increased by seizures and contributes to aberrant network reorganization in the adult rat hippocampus. J Neurosci 17:3727-3738.

Peters A, Kaiserman-Abramof IR (1970) The small pyramidal neuron of the rat cerebral cortex: the perikaryon, dendrites and spines. Am J Anat 127:321-355.

Pfeifer M, Boncristiano S, Bondolfi L, Stalder A, Deller T, Staufenbiel M, Mathews PM, Jucker M (2002) Cerebral hemorrhage after passive anti-A $\beta$ immunotherapy. Science 298:1379.

Priller C, Bauer T, Mitteregger G, Krebs B, Kretzschmar HA, Herms J (2006) Synapse formation and function is modulated by the amyloid precursor protein. J Neurosci 26:7212-7221.

Racke MM, Boone LI, Hepburn DL, Parsadainian M, Bryan MT, Ness DK, Piroozi KS, Jordan WH, Brown DD, Hoffman WP, Holtzman DM, Bales KR, Gitter BD, May PC, Paul SM, DeMattos RB (2005) Exacerbation of cerebral amyloid angiopathy-associated microhemorrhage in amyloid precursor protein transgenic mice by immunotherapy is dependent on antibody recognition of deposited forms of amyloid $\beta$. J Neurosci 25:629-636.

Richardson CL, Tate WP, Mason SE, Lawlor PA, Dragunow M, Abraham WC (1992) Correlation between the induction of an immediate early gene, zif/268, and long-term potentiation in the dentate gyrus. Brain Res 580:147-154.

Rougon G, Deagostini-Bazin H, Hirn M, Goridis C (1982) Tissue- and developmental stage-specific forms of a neural cell surface antigen linked to 
differences in glycosylation of a common polypeptide. EMBO J $1: 1239-1244$.

Santarelli L, Saxe M, Gross C, Surget A, Battaglia F, Dulawa S, Weisstaub N, Lee J, Duman R, Arancio O, Belzung C, Hen R (2003) Requirement of hippocampal neurogenesis for the behavioral effects of antidepressants. Science 301:805-809.

Schenk D, Barbour R, Dunn W, Gordon G, Grajeda H, Guido T, Hu K, Huang J, Johnson-Wood K, Khan K, Kholodenko D, Lee M, Liao Z, Lieberburg I, Motter R, Mutter L, Soriano F, Shopp G, Vasquez N, Vandevert C, et al. (1999) Immunization with amyloid- $\beta$ attenuates Alzheimer-disease-like pathology in the PDAPP mouse. Nature 400:173-177.

Schmidt ML, Robinson KA, Lee VM, Trojanowski JQ (1995) Chemical and immunological heterogeneity of fibrillar amyloid in plaques of Alzheimer's disease and Down's syndrome brains revealed by confocal microscopy. Am J Pathol 147:503-515.

Schroeter S, Khan K, Barbour R, Doan M, Chen M, Guido T, Gill D, Basi G, Schenk D, Seubert P, Games D (2008) Immunotherapy reduces vascular amyloid- $\beta$ in PDAPP mice. J Neurosci 28:6787-6793.

Shankar GM, Li S, Mehta TH, Garcia-Munoz A, Shepardson NE, Smith I, Brett FM, Farrell MA, Rowan MJ, Lemere CA, Regan CM, Walsh DM, Sabatini BL, Selkoe DJ (2008) Amyloid- $\beta$ protein dimers isolated directly from Alzheimer's brains impair synaptic plasticity and memory. Nat Med 14:837-842.

Shors TJ (2008) From stem cells to grandmother cells: how neurogenesis relates to learning and memory. Cell Stem Cell 3:253-258.

Snyder JS, Hong NS, McDonald RJ, Wojtowicz JM (2005) A role for adult neurogenesis in spatial long-term memory. Neuroscience 130:843-852.

Thored P, Heldmann U, Gomes-Leal W, Gisler R, Darsalia V, Taneera J, Nygren JM, Jacobsen SE, Ekdahl CT, Kokaia Z, Lindvall O (2009) Longterm accumulation of microglia with proneurogenic phenotype concomitant with persistent neurogenesis in adult subventricular zone after stroke. Glia 57:835-849.

Udo H, Yoshida Y, Kino T, Ohnuki K, Mizunoya W, Mukuda T, Sugiyama H (2008) Enhanced adult neurogenesis and angiogenesis and altered affec- tive behaviors in mice overexpressing vascular endothelial growth factor 120. J Neurosci 28:14522-14536.

van Praag H, Christie BR, Sejnowski TJ, Gage FH (1999) Running enhances neurogenesis, learning, and long-term potentiation in mice. Proc Natl Acad Sci U S A 96:13427-13431.

van Praag H, Schinder AF, Christie BR, Toni N, Palmer TD, Gage FH (2002) Functional neurogenesis in the adult hippocampus. Nature 415:1030-1034.

van Praag H, Shubert T, Zhao C, Gage FH (2005) Exercise enhances learning and hippocampal neurogenesis in aged mice. J Neurosci 25:8680-8685.

Verret L, Jankowsky JL, Xu GM, Borchelt DR, Rampon C (2007) Alzheimer's-type amyloidosis in transgenic mice impairs survival of newborn neurons derived from adult hippocampal neurogenesis. J Neurosci 27:6771-6780.

West MJ, Slomianka L, Gundersen HJ (1991) Unbiased stereological estimation of the total number of neurons in thesubdivisions of the rat hippocampus using the optical fractionator. Anat Rec 231:482-497.

Wilcock DM, Rojiani A, Rosenthal A, Subbarao S, Freeman MJ, Gordon MN, Morgan D (2004a) Passive immunotherapy against A $\beta$ in aged APPtransgenic mice reverses cognitive deficits and depletes parenchymal amyloid deposits in spite of increased vascular amyloid and microhemorrhage. J Neuroinflammation 1:24.

Wilcock DM, Rojiani A, Rosenthal A, Levkowitz G, Subbarao S, Alamed J, Wilson D, Wilson N, Freeman MJ, Gordon MN, Morgan D (2004b) Passive amyloid immunotherapy clears amyloid and transiently activates microglia in a transgenic mouse model of amyloid deposition. J Neurosci 24:6144-6151.

Wilcock DM, Gordon MN, Morgan D (2006) Quantification of cerebral amyloid angiopathy and parenchymal amyloid plaques with Congo red histochemical stain. Nat Protoc 1:1591-1595.

Zhao C, Deng W, Gage FH (2008) Mechanisms and functional implications of adult neurogenesis. Cell 132:645-660.

Zhao C, Teng EM, Summers RG, Jr., Ming GL, Gage FH (2006) Distinct morphological stages of dentate granule neuron maturation in the adult mouse hippocampus. J Neurosci 26:3-11. 